\title{
The Contemporary Art Scene in Syria
}

This book focuses on the expanding contemporary art scene in Syria, particularly Damascus, during the first decade of the twenty-first century. The decade was characterized by a high degree of experimentation as young artists began to work with artistic media that were new in Syria, such as video, installation and performance art. They were rethinking the role of artists in society and looking for ways to reach audiences in a more direct manner and address socio-cultural and socio-political issues.

The Contemporary Art Scene in Syria will be of interest to scholars of global and Middle Eastern art studies, and also to scholars interested in the recent social and cultural history of Syria and the wider Middle East.

Charlotte Bank is an art historian and independent curator with a $\mathrm{PhD}$ in Arabic from the University of Geneva.

Cover image: Visual Art Festival, Damascus 2010, view of opening celebration, Zaituna Square, Damascus. Photo credit: Salah Saouli. 


\title{
Routledge Advances in Art and Visual Studies
}

This series is our home for innovative research in the fields of art and visual studies. It includes monographs and targeted edited collections that provide new insights into visual culture and art practice, theory, and research.

\author{
Abstract Painting and the Minimalist Critiques \\ Robert Mangold, David Novros, and Jo Baer in the 1960s \\ Matthew L. Levy \\ Arte Ambientale, Urban Space, and Participatory Art \\ Martina Tanga \\ Theory of the Art Object \\ Paul Crowther
}

The Digital Interface and New Media Art Installations

Phaedra Shanbaum

Ecocriticism and the Anthropocene in Nineteenth Century Art and Visual Culture

Edited by Emily Gephart and Maura Coughlin

Popularization and Populism in the Visual Arts

Attraction Images

Edited by Anna Schober

Dialogues Between Artistic Research and Science and Technology Studies

Edited by Henk Borgdorff, Peter Peters, and Trevor Pinch

Contemporary Art and Disability Studies

Edited by Alice Wexler and John Derby

The Outsider, Art and Humour

Paul Clements

The Contemporary Art Scene in Syria

Social Critique and an Artistic Movement

Charlotte Bank

For a full list of titles in this series, please visit https://www.routledge.com/RoutledgeAdvances-in-Art-and-Visual-Studies/book-series/RAVS 


\title{
The Contemporary Art Scene in Syria
}

Social Critique and an Artistic Movement

Charlotte Bank

\author{
Routledge


First published 2020

by Routledge

52 Vanderbilt Avenue, New York, NY 10017

and by Routledge

2 Park Square, Milton Park, Abingdon, Oxon OX14 4RN

Routledge is an imprint of the Taylor \& Francis Group, an informa business

(C) 2020 Taylor \& Francis

The right of Charlotte Bank to be identified as author of this work has been asserted by her in accordance with sections 77 and 78 of the Copyright, Designs and Patents Act 1988.

All rights reserved. No part of this book may be reprinted or reproduced or utilised in any form or by any electronic, mechanical, or other means, now known or hereafter invented, including photocopying and recording, or in any information storage or retrieval system, without permission in writing from the publishers.

Trademark notice: Product or corporate names may be trademarks or registered trademarks, and are used only for identification and explanation without intent to infringe.

Library of Congress Cataloging-in-Publication Data

Names: Bank, Charlotte, author.

Title: The contemporary art scene in Syria : social critique and an artistic movement /

Charlotte Bank.

Other titles: Contemporary art scene in Syria (Routledge (Firm))

Description: New York : Routledge, 2020. |

Series: [Routledge advances in art and visual studies] |

Based on the author's thesis (Ph. D.)--Université de Genève, 2017, under the title:

Contemporary art scene in Syria 2000-2010 : between the legacy of social critique and a contemporary artistic movement in the Arab world. |

Includes bibliographical references and index.

Identifiers: LCCN 2020001296 (print) | LCCN 2020001297 (ebook) |

ISBN 9780367244781 (hardback) | ISBN 9780429282713 (ebook)

Subjects: LCSH: Art and society--Syria--History--21st century. |

Art, Syrian--21st century.

Classification: LCC N72.S6 B33 2020 (print) |

LCC N72.S6 (ebook) |

DDC 709.5691/090511--dc23

LC record available at https://lccn.loc.gov/2020001296

LC ebook record available at https://lccn.loc.gov/2020001297

ISBN: 978-0-367-24478-1 (hbk)

ISBN: 978-0-429-28271-3 (ebk)

Typeset in Sabon

by Taylor \& Francis Books 


\section{Contents}

List of figures $\quad$ vii

Acknowledgements $\quad$ ix

Introduction 1

The Structure of the Book 8

Notes on Transliteration and Titles 10

1 "Culture Is Humanity's Highest Needs": Art and Artists between Autonomy and Coercion

1.1 Art as an Index of Modernity and Progress: The Syrian "Pioneer" Tawfiq Tarek 14

1.2 The Artist and the State: Navigating Artistic Freedom, Censorship and Threats of Co-Optation 19

1.3 Hopes for Change: Artists and the Artistic Infrastructure in the 2000s under Bashar al-Assad 29

Conclusion 38

2 Commitment, Critique and the Power of Imagination

2.1 Artist-Citizen: Commitment and Critique in Syrian Art 46

2.2 Balancing on the Edges: Being an Artist in Twenty-First-Century Syria 52

2.3 Searching for Renewal: Video and Installation Art as Locations of Critique 55

2.4 Whose Art? The Audiences and Reception of Critical Art in Syria 58 Conclusion 60

3 Creating Meaning in Visual Art: Technique, Critique and Subject Matter

3.1 On the Borders of Official Ideology: The Issue of Palestine Between Activism and Metaphor 65

3.2 Hidden Menaces: The Metaphor of the Abyss 77 
vi Contents

3.3 Critique of Societal Rigidity 84

3.4 Counter-Narratives: When Artists Challenge Official Discourse and Taboos 91

Conclusion 101

4 Singing in the Kingdom of Silence: Syrian Artists and the International Art World

4.1 "Branding” Contemporary Arab or Middle Eastern Art 112

4.2 The Missing Link: Syrian Artists and Their Relative Invisibility on the International Art Scene 116

4.3 Increased International Visibility of Syrian Artists after 2011118

Conclusion 128

Conclusion

Bibliography

138

Index 


\section{Figures}

1.1 Tawfiq Tarek, Abu 'Abd Allah as-Saghir, oil on canvas, 100 x $80 \mathrm{~cm}, 1322$ AH / 1903-1904 AD, Damascus National Museum

1.2 Oussama Mohammad, Nujum al-nahar (Stars in Broad Daylight), 1988, $33 \mathrm{~mm}$ film

1.3 All Art Now, Performance Fatigue Fracture by Markus Keim and Beate Hecher, 2010

1.4 Visual Art Festival, Damascus 2010, exhibition of video art

1.5 Conference, “Arab Art in a Changing World”, 2010, organized by Rafia Gallery

1.6 Atassi Gallery, exhibition view. Works by Marwan 36

3.1 Ammar Al-Beik, Jerusalem HD, 2007, video 66

3.2 Ammar Al-Beik, Samia, 2008, video 67

3.3 Buthayna Ali, I'm Ashamed, 2009, mixed media installation 70

3.4 Adham Ismail, Family of Refugees in Abu Rummaneh Street or The Refugees, 1950, oil on canvas, $65 \times 85 \mathrm{~cm}$

3.5 Louay Kayali, Thumma madha (Then What?), 1965, oil on canvas, $172 \mathrm{x}$ $190 \mathrm{~cm}$

3.6 Marwan Kassab-Bachi, Three Palestinian Boys, 1970, oil on canvas, $130 \mathrm{x}$ $162 \mathrm{~cm}$

3.7 Rami Farah, Point, 2005, video

3.8 Hrair Sarkissian, Execution Squares, 2008, archival inkjet print, $125 \times 160 \mathrm{~cm}$

3.9 Youssef Abdelké, People, No. 10, 1993, etching, 63 × $50 \mathrm{~cm}$

3.10 Fateh Al-Moudarres, The Beast and the Commoner [al-Wa'ash walMaskeen], 1987, oil on canvas, 76 × $55 \mathrm{~cm}$

3.11 Youssef Abdelké, Fish, 2015, charcoal on paper, $145 \times 275 \mathrm{~cm}$

3.12 Soudade Kaadan, Madinatayn wa sijn (Two Cities and a Prison), 2008, video

3.13 Hazem Alhamwi, Asfur hajar (Stone Bird), 2004, video

3.14 Hazem Alhamwi, Asfur hajar (Stone Bird), 2004, video 87

3.15 Samer Barkaoui, Poster, 2004, video 91

3.16 Reem Al-Ghazzi, Adwa' (Lights), 2009, video 92

3.17 Reem Al-Ghazzi, Adwa' (Lights), 2009, video 92

3.18 Ammar Al-Beik, Innahum kanu huna (They Were Here), 2000, video 95

3.19 Adham Ismail, Al-hammal (The Porter), oil on canvas, 80 x 100 cm, $1951 \quad 96$

3.20 Reem Ali, Zabad (Foam), 2008, video 97

3.21 Reem Al-Ghazzi, Shuq (Crack), 2007, video 99

3.22 Rami Farah, Samt (Silence), 2006, video 99 


\section{viii Figures}

3.23 Mohamad Malas, Al-Layl (The Night), 1992, $33 \mathrm{~mm}$ film

4.1 Mohammad Omran and Dani Abo Louh, Conte de printemps (A Spring's Tale), 2011, video

4.2 Ammar Al-Beik, Hadinat al-shams (The Sun's Incubator) 2011, video

4.3 Akram Halabi, From the Cheek Series, 2013, digital print on paper, $50 \mathrm{x}$ $85 \mathrm{~cm}$, Edition $1 / 6$

4.4 Kevork Mourad and Kinan Azmeh, A Sad Morning, Every Morning, 2012, video

4.5 Iman Hasbani, Here, There, and Other Places, 2017, immersive installation. Art-Lab Berlin in collaboration with Shubbak Festival, London

4.6 Yaser Safi, Extract from a Diary, 2012-2013, 30 x $42 \mathrm{~cm}$, ink on paper

4.7 Mohammad Omran, Untitled, 2014, ink on carton, $21 \times 21 \mathrm{~cm}$

4.8 Marwan Kassab-Bachi, Der Gemahl (The Husband), 1966, oil on canvas, $190 \times 130 \mathrm{~cm}$ 


\section{Acknowledgements}

This book is in many ways a labour of love. The research at its basis was begun during the 2000s as a curatorial project triggered by some puzzling ideas about the non-existence of any interesting contemporary artists in Syria, that I read. It developed into a dissertation project, which I was happy to conclude at the University of Geneva in 2017 under the supervision of Professor Silvia Naef. I would like to thank her for invaluable support she has offered me throughout the project, since I presented my initial idea to her. A position as research assistant in the project Other Modernities: Patrimony and Practices of Visual Expression Outside the West, funded by the Swiss National Science Foundation, allowed me to concentrate on my research and writing through a three-year grant. The project managers and my colleagues in the SNSF-funded Sinergia project offered valuable advice during the discussions we had at our regular meetings. A grant from the Fondation Schmidheiny in Geneva allowed me to finish my dissertation and a three-month doctoral fellowship at the Orient Institut in Beirut in 2016 allowed me to supplement my initial research with newer findings related to Syrian artists and their work since the beginning of the uprising as well as to consult a number of private archives and libraries. On this occasion, Saleh Barakat of Agial Gallery in Beirut kindly offered me access to his collection of books and catalogues. Since travelling to Damascus was out of the question, his help was invaluable.

After finishing my $\mathrm{PhD}$, a postdoctoral fellowship of International Scholarship Program at the Staatliche Museen zu Berlin - Preußischer Kulturbesitz gave me the opportunity to spend three months at the Museum of Islamic Art, which I used as a basis to carry out research among displaced Syrian artists in Berlin. It gave me the opportunity to catch up with artist friends from Damascus and also make some new acquaintances.

During my stays in Syria between the years 2007-2010, I was lucky to meet a great number of people who shared with me their thoughts about the role of art in Syria and the importance of allowing a space for young artists and new, contemporary media. I would like to thank Diana El-Jeiroudi, Orwa Nyrabia and Firas Chehab for their help and advice at the beginning of my research and Abir and Nisrine Boukhari from All Art Now, Myriam Jakiche of Ayyam Gallery and Rafia Kodmani of Rafia Gallery for sharing their thoughts about the contemporary art scene in Syria with me during those exciting years, when the art scene in Damascus seemed so promising.

I would like to thank the artists Dani Abo Louh, Ammar Al-Beik, Reem Al-Ghazzi, Hazem Alhamwi, Buthayna Ali, Reem Ali, Mustafa and Samer Barkaoui, Rami Farah, Mohamad Malas, Oussama Mohammad, Kevork Mourad, Mohammad Omran, Yaser Safi and Hrair Sarkissian for sharing their works with me and Mohamad Malas for our discussions about the importance of uncompromising aesthetics in cinema and the arts. 


\section{$\mathrm{x}$ Acknowledgements}

Later, in Beirut, Youssef Abdelké discussed ideas of artistic critique and the commitment of artists with me. I am grateful to Soudade Kaadan for our long, ongoing conversation on the importance of cinema and art, a conversation that is resumed whenever we meet in various places, be it Rotterdam, Beirut, Florence, Geneva or Istanbul.

Over the course of the years I have shared many hours with the painter Marwan, who spent his life between Damascus and Berlin, discussing topics as varied as commitment in art, the meaning of home and our common love for Damascus and its light. Sadly, he left us before I finished my thesis and therefore will never get to see this book. I still miss our conversations.

I would like to thank Mouna Atassi for sharing some of her thoughts on Syrian art, from the early days of modern art till the most recent contemporary production with me. I thank Shireen Atassi of the Atassi Foundation for her help in locating and providing images, Sultan Al Qassimi and Suheyla Takesh of the Barjeel Foundation provided images from their collection, and Ead and Maya Samawi of Ayyam Gallery helped me access images from the Samawi Collection.

I thank Anneka Lenssen and Kirsten Scheid for their help in locating forgotten texts.

I am indebted to Delphine Leccas, with whom I have had the pleasure of working on a number of curatorial projects in Syria and Europe and who has shared with me aspects of her experience and knowledge of the art world in Syria.

Various aspects of my research have been presented at international conferences. Grants from the Swiss Academy of Humanities and Social Sciences and the Sociéte académique de Genève allowed me to travel to and participate in WOCMES (World Congress of Middle Eastern Studies) in Ankara in 2014 and the AMCA/CIADA conference in Singapore in 2015 and to discuss my findings with international colleagues.

Salah Saouli supported this work from the beginning and offered much valuable advice. I thank him for his patience in discussing my ideas and the interest he always showed in my work.

I would also like to thank my mother for her support throughout the years. I only wish I could also have shared this book with my father. 


\section{Introduction}

This book discusses the contemporary art scene in Syria during the first decade of the twenty-first century in its regional and art-historical context. It examines how young artists sought to re-think the role of artists in society and create a space to re-imagine the world through their work and thus inspire change in the socio-cultural and socio-political spheres. This coincided both with an expansion of the local art scene and the opening of new art spaces and galleries and a growing international interest in contemporary artistic production from the non-West, and with it from the Middle East, in the so-called "global turn" of the international art world.

Although artists from Syria might have been expected to have good prospects in this context, they were comparatively underrepresented on the circuit of biennials, festivals and large-scale exhibitions that proliferated during the 2000s and professed to offer an overview of the artistic production of this vast and diverse region. There are several reasons for this lack of visibility. Syria was, compared to neighbouring Lebanon, considerably less accessible for foreign curators. No contemporary art institutions existed at the beginning of the decade that were well connected to the international scene and immersed in contemporary artistic and cultural discourse, and Syrian artists were generally less mobile and often suffered from rigid visa rules when attempting to travel on an international scale. Furthermore, the country lacked a large artistic and intellectual diaspora, unlike Lebanon and Palestine, an important factor that often proved helpful in securing artists from these locations their place on the global art scene.

While international curators interested in visiting Syria might have faced an array of practical obstacles, many also appeared highly dismissive of artistic production in Syria. Therefore, their negative views were often based on short, superficial visits to the country (or in some cases, no visit at all). To give a telling example, the curator of the exhibition "DisOrientation" at the House of World Cultures in Berlin in 2003, Jack Persekian, visited Damascus briefly in the summer of 2002 to meet artists and what he termed "gallery people", and wrote the following in the catalogue of the afore-mentioned exhibition: "What I saw, ..., did not go beyond self-indulgent orthographies and anachronistic development." It was judgements such as these that triggered my initial interest in the contemporary art scene in Syria. These criticisms seemed odd in their harshness, particularly in light of the tradition of fine art and filmmaking in the country. And they made me curious to see for myself what the contemporary art scene in Syria was like. But although Syria was not unknown to me, as I had visited the country on numerous occasions before, I had to wait several years, before I was able to travel to Syria and undertake research on-site with a travel grant for an artistic project from the Danish Institute in Damascus. I travelled to Damascus in February 2007 to embark on a 


\section{Introduction}

project focusing on the young, experimental documentary video scene. Prior to leaving, I had succeeded in locating one contact online, Diana El-Jeiroudi of Proaction Film, and once I had arrived in Damascus, Diana and her partner Orwa were kind enough to introduce me to some of their contacts. This allowed me to begin building my own network through a snowball system and this was the beginning of a long informal research project that led to several film and video programmes, exhibitions, a PhD project and, ultimately, to this book.

Although I had expected to meet obstacles, even occasional distrust, among artists, I was pleased with the steady progress of my research. I met a group of young artists and filmmakers and videomakers, who had begun experimenting with contemporary artistic media and modes of expression. They came from a variety of educational backgrounds, many had received their training at the High Institute of Dramatic Arts and were now working with video, some had studied at the Faculty of Fine Arts at the University of Damascus, others came from the humanities or other academic disciplines, while still others described themselves as autodidactic artists. Only very few had studied film, because, as Syria did not have a film school, this would have meant going abroad to study, something that presented significant obstacles to young Syrians due to travel and visa restrictions. The majority of these artists were highly critical of what they called the "backwardness" of the University of Damascus' Faculty of Fine Arts and of the entire official, state-sponsored artistic and cultural scene, such as exhibitions, festivals and other events organized by the Ministry of Culture and the Faculty. They seemed keen on redefining their roles as artists in Syrian society, reaching new audiences, addressing critical social issues and even touching upon sensitive taboos or, in some cases, openly challenging conventions of Syrian society and politics. While constantly searching for new aesthetic approaches to address these themes and working their ways around censorship, many mentioned Omar Amiraly, a prominent Syrian documentary filmmaker, as an important inspiration for their own understanding of an engaged, aesthetically innovative art. In their radical search for a new aesthetic language and a redefinition of the role of art within Syrian society, they practised a kind of institutional critique, if we understand this as a critique of art and its institutions as a means to preserve a status quo perceived as stifling.

The 2000s were a period of numerous transitions. A number of my interview partners had placed high hopes in Bashar al-Assad's transition to power after the death of his father Hafiz al-Assad in 2000, hopes he had inspired during his first public appearances as president of the country, and these hopes were shared by large parts of Syrian society (and a considerable number of foreigners as well). Shortly after the death of Hafiz al-Assad, visual artists, filmmakers, writers, journalists and other intellectuals had joined forces in the "civil society movement", also known as the "Damascus Spring movement" and formulated calls for democratic reforms. It was a brief period which lasted until autumn 2001 and saw the organization of political salons in the private homes of the protagonists. Lively discussions took place about Syria's political future as a democratic state and free society, but sadly, such hopes were soon crushed and a large number of advocates for freedom were imprisoned or otherwise forced into silence. Although this was a significant setback, it did not mean an end to artists' advocacy for freedom and change in the country. Rather, the first decade of the twenty-first century witnessed a new generation of artists who took up the legacy of critical, socially committed art, even occasionally venturing onto the dangerous terrain of political critique. Just as former generations of fine artists, writers and filmmakers had used the means available to them, so all my interview partners seemed eager to use the limited opportunities at their disposal to work for social change. 
However, like their older peers, these young artists were also subject to state censorship. Even though Syria seemed, on the surface, more open during the first decade under Bashar al-Assad, censorship remained in place and arbitrary rules of what was permitted and what was not were as fluctuating as they had been during the regime of Hafiz. There maybe was a slightly more permissive climate and more work might have passed the censors, but all artistic and cultural production continued to remain subject to censorship, while a lack of openness and clear rules added to a general feeling of uncertainty. Former generations of artists had often expressed critique through elaborate metaphors and symbols, but the young generation was longing for a more direct language. Yet, because of the severe restrictions they faced when they tried to push the boundaries of permitted speech, they often had to revert to old and well-tested solutions.

The atmosphere throughout the decade oscillated between hope and despair, between bustling energy and apathy: on the one hand, artists tried to see the signs of change positively, hoping that the long-term situation of the arts in Syria would improve; on the other hand, they were constantly faced with evidence that effective change was still far away and their own situation as artists as fragile as ever. Adding to this was a feeling of cultural isolation, from which many wished to break free. Former generations of artists had had the possibility of studying abroad, facilitated by a number of exchange programmes with socialist countries which had stopped with the fall of the Iron Curtain. New travel and visa restrictions now made such travel almost impossible. Young artists without connections to people close to the regime and without strong financial backing were largely prevented from travelling and thus felt they were being doubly punished for being Syrian.

My initial stay in February 2007 led to a series of longer periods of sojourn in the following years, during which I expanded my network and met numerous artists and cultural producers. I conducted a series of informal interviews and conversations with artists and collected an archive of videos, films, photos, and field notes in the process. It is this archive that forms the basis of the present work. My interaction with artists and cultural producers mostly happened in those Damascene cafés, where the artists used to meet regularly to discuss their ideas. Occasionally, I would meet the artists in their studios or workspaces and sometimes meetings would take the form of extended lunches and dinners, where the strict lines between professional and leisurely, personal conversation were blurred.

The material I collected in Syria was of quite an ephemeral character. Written sources related to the independent art scene in Syria were never abundant, and mostly were entirely absent. Some artists had portfolios that included texts and images of their work, and sometimes smaller publications, which they shared with me, but only very few artists had a website. This changed only with the uprising. Some exhibitions and events were accompanied by small catalogues. Most artists gave me copies of their films, videos and photos of their work and were happy to discuss their work with me but did not provide any written material. Press material was largely absent from the exhibitions and events, in which my contacts had participated, and, if present, tended to be superficial, largely descriptive, very basic, and, as I perceived it at the time, lacking in critical quality. At the time of my research, I therefore dismissed it as irrelevant and did not collect any of it. In hindsight, this is regrettable, as this material would also have been useful to retrospectively analyse the parameters of the contemporary art scene in Syria during the 2000s. The collected material gave rise to a series of public lectures and a number of film and video programmes which I have curated for institutions in Europe, an enjoyable 
opportunity to present works that until then had received little international attention from interested audiences. ${ }^{2}$

The years 2007-2010 witnessed an important development in new artistic and cultural initiatives: in 2008, the festival for creative documentary film "Dox Box" was inaugurated, 2009 saw the first video art festival, organized by the contemporary art initiative All Art Now, and a festival for experimental dance was also initiated in 2009. New galleries opened which claimed an interest in a more conceptual, thematic approach and many more activities were initiated, all adding to the feeling of a vibrant art scene. The artists in my network were part of this emerging scene yet remained sceptical of many of its aspects. In particular, the rise of new, fashionable galleries with their subsequent commercialization of the art scene was criticized on numerous occasions, as it made it even harder for artists to pursue non-commercial interests and maintain a socially critical position. There was also a feeling among many that the economic opening of the country had led to a loss of social coherence and to a general alienation, that what was "genuinely Syrian" was being sold off and the fabric of Syrian society given a fake polish, in order to cover up for the lack of personal freedom and security. At the same time, and paradoxically, there was a strong desire to catch up with the international art scene, to claim a place on the regional scene and to be part of contemporary artistic and cultural practices.

The lack of exhibition space for non-commercial art and techniques other than painting and sculpture remained one of the major problems throughout the decade, despite the initiatives mentioned above. Foreign cultural centres offered a small space of relative freedom, often taking on the task of compensating for the lack of exhibition and screening opportunities for young, lesser-known artists, something which led to them being regarded as important venues by many of my interview partners. These centres (mainly the Centre Culturel Français and the Goethe Institute) were often able to show works of a more critical character than would have been possible at other venues, where they would have been deemed problematic for political reasons.

All these factors made the 2000s a fascinating, but brief episode in the history of art in Syria. It was a time of experimentation and important changes with young artists taking up new forms of expression and private initiatives that sought to expand ideas of suitable venues of viewing art and modes of representation. Beginning with tentative first steps, this young and dynamic movement grew in strength throughout the decade, only to be crushed after the beginning of the popular uprising in early 2011.

During the first year of the revolt, and after a period of hesitation that lasted some months, many artists began to use their work to express solidarity with the peaceful, popular movement for change and to condemn the violence perpetrated by the forces of order against the protestors on the streets. Many of the artists, who had been part of the video movement during the 2000s, were engaged in such activist work. They became involved as trainers, by lending out equipment, but they also used their artistic work for activist means. In general, the new post-2011 works were bolder and more direct than the work of the previous decade. However, the foundation laid for them during that period is undeniable and its importance is emphasized.

The significance of the artistic production between 2000 and 2010 thus lies in its transitional role. It represents a breaking free from certain rigid aesthetics that arguably had guided much of Syrian art up to that point. It was the period in which Syrian artists started working with contemporary artistic media, such as video, installation and performance, practices which have greatly gained in importance since the beginning of 
the uprising. Thus, while the Syrian art scene was halted in its smooth development, the changes initiated during the 2000s paved the way for new practices that flourished after 2011 when the artistic environment once again changed substantially. Art in Syria has generally not received much scholarly attention, and this is especially true for the 2000s. It is therefore a period that easily risks falling into oblivion. Yet, I would argue that any attempt to reach an in-depth understanding of Syrian artistic production (or that of Syrian artists who relocated to other countries) since 2011 will need to consider the developments of the preceding ten years. The ease with which artists turned their attention to new technology and to the internet as a space for both dissemination and discussion of art after the beginning of the uprising is hard to imagine without the groundwork laid during the decade leading up to 2011.

Scholarly work on artistic production in Syria remains largely marginal within the wider field of modern and contemporary Middle Eastern art. This turns every new work into an almost "pioneering" endeavour, each piece adding to the body of knowledge and representing a re-thinking of some of its aspects. During the initial stages of my research, I was very interested in miriam cooke's notion of "commissioned critique". 3 It has proved helpful when considering critical works of earlier generations of artists, but less applicable in the context of the young artists working in the 2000s, who produced their work outside state-sponsored institutions. cooke uses the term to describe practices of permitting and even funding the production of critical artworks, works that the state would later use for its own aims, while keeping the artists, filmmakers or writers unsure of the reasons behind this leniency and always afraid of a later crackdown. One particularly striking example of this is the auteur films of the 1980s and 1990s, that were produced by the state film institution, Al-mu'assassa al-'amma li-l-sinema (mostly referred to as National Film Organization, NFO in English). These films were of a high artistic standard and were often sent to international film festivals, but were censored at home and never released in Syrian cinemas. Lisa Wedeen's concept of "as if" is useful when understanding the necessity to perform political conformity without the necessity of actual belief. As she argues, it is not the conviction of the truthfulness of claims made by the regime which was essential, but rather the pretence of believing them. ${ }^{4}$ This necessity of keeping up a façade of conformity is known from other authoritarian contexts, as is the withdrawal of critique into the realm of private jokes and metaphorical language. In my wish to understand the official culture industry in Syria with its system of censorship, coercion and favours, Cecile Boëx's dissertation on the state-sponsored film industry was invaluable, as it offers an idea of the structures that young artists were criticizing and rebelling against. ${ }^{5}$ For a historical perspective of how the art and culture scene in Syria had developed since national independence in 1946 up to the crisis of 1967, following the Six Days' War with Israel, Anneka Lenssen's dissertation offered a wealth of first-hand sources with an in-depth analysis of the social and political context. ${ }^{6}$

The official art scene will not figure prominently in this book. It did not interest me at the time of my stays in Syria and I did not include it in my field research. I was more interested in how the independent art scene organized itself and how young artists managed to get the training they wanted in media not included in the art school curriculum, as well as the channels through which they made their works available to their audiences. The independent and informal character of my research and my status as an independent, unaffiliated researcher might possibly also have complicated any attempts to be more involved with the official art scene. Lacking an institutional affiliation certainly did close some doors, but it might have opened others. ${ }^{7}$ I wanted to understand how 
young artists defined their practice as oppositional to the official art scene and state authoritarianism. That these artists were willing to discuss such critical issues with me might be partially explained by my unofficial status, in other words, that I was not seen as posing a threat. The resulting informality of my contacts had a substantial influence on the style of my research. I made the deliberate choice not to force a rigid, standardized scheme onto my interviews, but chose to conduct them in a friendly, informal climate, meeting the artists regularly and also remaining in contact with them when I was in Europe. I only rarely recorded the interviews. I soon realized that a recording device created a tense atmosphere that ran counter to my self-understanding as a researcher and that artists would not be comfortable sharing their concerns with me if their words were caught on tape. Keeping my informal method allowed me to develop lasting friendships with many of my contacts, friendships that are still intact, even now that most of them have relocated to other cities in the Middle East or Europe.

Supplementing my initial findings with further research on the state-controlled art scene would surely have been of great value. Besides constituting the structures that the independent initiatives sought to position themselves against, its importance also lies in the fact that it involved those teaching the young generations of artists as well as those guaranteeing exhibition opportunities within the recognized artistic circles of Syria. So, while its importance for such a study as mine is undeniable, the steadily deteriorating situation in Syria since I began turning my initial research into a dissertation project unfortunately crushed any hope of returning to the country for additional research. For this reason, I have to leave this aspect aside here and hope that future researchers might get a chance to fill in these gaps.

Another aspect of art production that I did not include in my initial research was those artists involved in the production of the official celebratory paintings and sculptures of the Syrian president and his family that populated the streets and buildings of the country. While certainly also an interesting subject of study, this was very far from my personal interests at the time.

The Syrian artists whose works I will discuss in this book, all produced their art from an engaged, critical position, believing in the power of art to inspire change. I have found ideas of art as a way of "worldmaking" useful when thinking about this social project of Syrian artists and the effects that the artists hoped their works would have. As discussed by the art historian Marsha Meskimmon and the artist and theorist Dan S. Wang, art can function as "an active constituent of meaning production, rather than a mute 'mirror' onto the world" and a location for the world to be imagined differently. ${ }^{8}$ Under constraining conditions, whether economic or political, art might even be the only space in which such imagination is possible when all other options might be stifled. ${ }^{9}$ Under conditions that differ strongly from those of Western democracies, artists sometimes take on the role of articulating not only social, but also political alternatives. Thus, during the Pahlavi era in Iran, what is known as Iranian New Wave Cinema offered a space to articulate political and social grievances and discuss alternative arrangements. ${ }^{10}$ Similarly, the criticality of Syrian art is very different from that of Western art. It was (and is) produced from a highly precarious position with constant risks for the artist, and the works produced are often much less outspoken than those of Western "committed" or "critical" artists. The restrictive conditions, under which they were produced, necessitated a veiled, metaphorical language, a language that called upon the audience to enter the mind of the artist and read between the lines. Syrian artists produced their critical works driven by a wish to engage their contemporary reality and to get their audience 
directly involved in their project of reimagining and remaking the world. When using the terms "committed" or "critical" for these works, it is important to keep this in mind, since all these aspects flow into the particular worldmaking project of Syrian artists.

Despite their misgivings about the way censorship infringed upon their freedom to produce, the young generation of artists was generally careful to avoid overly open confrontations with censors, though there are some important exceptions. But they were also eager to push the boundaries of what was permitted to talk about by using a subtle approach and applying what one might call a "strategy of small steps". ${ }^{11}$ Their project was an attempt to work for change from within society, not through open opposition and provocation. The anthropologist and writer Saddeka Arebi described a similar approach she called "measured challenge and response", as used by Saudi Arabian women writers: "resistance, if too organized and apparent, may spark alarm and lead to increasing opposition", ${ }^{12}$ but, she goes on to write, "if resistance is too masked or hidden, it may be incorporated as a means by which the dominant discourse displays its tolerance for opposite views and [one] may confuse this tolerance with participation". ${ }^{13}$ This neatly sums up the difficult working situation of artists working in authoritarian contexts, regardless of their chosen medium. Artists living and working under such conditions are caught in a continuous and tiresome balancing act, relentlessly assessing and reassessing their work and the risks involved. Despite this, they continue to produce and often succeed in making strong and surprisingly outspoken works.

To write this book, I have relied on my notes from the days of my field research. While preparing my dissertation at the University of Geneva, I attempted to follow up with some artists of my network and talk about different aspects of the previous decade, but these talks were of only limited use, as the artists' memories of that period understandably were often coloured by the violent events that had followed since the uprising began in 2011. Interviews about the past are always challenging due to the selective nature of memory, but this is especially true in the context of political activity and repression, engaged and critical artistic practice included. ${ }^{14}$

When discussing art and artists in Syria, I am using these terms in a broad sense, including the fine arts with its different disciplines as well as cinema that does not fall into the category of mainstream entertainment cinema. Both practices, artistic and cinematic, are closely tied to one another in the context of my work, namely, the intellectual milieu of artists critical of the authoritarian Syrian state. These filmmakers and visual artists knew each other and participated in the same discussions. They were united by a common goal: to work for positive, social change in Syria. Though writers also formed part of these circles of critical, cultural producers, they will not be considered in depth here, I will, however, occasionally allude to works of literature. ${ }^{15}$ The work of many young artists that I discuss here often had an interdisciplinary character; it was not uncommon for them to work with video, photography, installation and performance. Many looked to cinema for inspiration and, in particular, the documentary filmmaker Omar Amiralay was seen as an important influence because of his understanding of a cinema as at once personal but also engaged and critical. While a discussion of visual art and cinema as closely linked practices might not immediately offer itself in all contexts, it makes sense here in order to ensure an in-depth discussion of individual artists and their work.

In this book, I am using the term "culture" in the lay sense of "high culture", meaning the production of artists, writers, musicians, scholars, and not in the anthropological sense of the term. I am situating the works of artists in their particular socio-political 


\section{Introduction}

context. More than perhaps any other scholar of non-Western culture and art, Edward Said has been influential in stressing the need to look at a subject in connection with its contemporaneity and context and not address these cultures as eternal and unchanging, as the European Orientalist tradition had. ${ }^{16}$ This principle has also guided me in my research and analysis of Syrian artists and their work in different periods of the history of modern and contemporary art. Due to the highly personal character of my research as it was fuelled by my curatorial interests and the manner in which my material was collected, I situate myself clearly within the text. Furthermore, I write from a position that regards art as a potentially powerful tool to articulate social and political concerns and to advocate for change of the status quo. In this, I follow the position of my interlocutors quite closely.

The starting point of this study is the artistic infrastructure and its rapid development during the second half of the 2000s as well as the young generation of critical artists' role in it. I will look closely at artists working in contemporary artistic media such as video and installation, since it is these media which have been of the greatest importance for artists with a socially critical approach during the period covered by this study. While critical, painted works have played an important role in the history of modern art in Syria, they only played a minor role in this artistic approach in the 2000s. I will link the works of this recent generation to what I propose to call "moments of criticality" in the works of earlier generations, i.e. artworks (painting and auteur films) that have taken a critical stance vis-à-vis current issues. In contrast to neighbouring Lebanon, artists in Syria have mostly seen themselves as critical, active members of society and have used their art as a vehicle to express their political and social concerns. Since the union of Syria and Egypt in the short-lived United Arab Republic (1958-1961), the Syrian state has formulated a cultural policy which stresses the role of artists in national progress and, since the Ba'ath Party came to power in 1963 , it has sought to actively influence artistic production. Many artists have, however, resisted where they could. That said, not all artists in Syria viewed themselves as oppositional or pursued a declaredly emancipatory or activist project. But, it would exceed the thematic scope of this study to consider those artists who have chosen to take an apolitical stance and concentrate on purely aesthetic questions.

\section{The Structure of the Book}

In Chapter 1, I focus on the historical, social and political context of artistic production in Syria. Beginning with a discussion of one of the first painters born in those Ottoman provinces that were later to become Syria, Tawfiq Tarek, and how he applied his art to articulate a critical stance on his contemporary society, I turn attention towards the political framework provided by the Syrian state throughout its history as well as how different state institutions, such as censors, have affected the working situation of artists. I conclude with a discussion of the changes in the art world and its infrastructure during the 2000s. Howard Becker's notion of the "art world" as networks of individuals, groups and institutions, all of whom contribute to the production, distribution, presentation and reception of art, has been useful when thinking about the Damascene art world and its participants. According to this understanding, an art world includes "workers" at every level involved in making works of art possible, from those offering different kinds of "support" work to the highly specialized artists themselves, as well as those involved in the presentation and reception of art. ${ }^{17}$ While these ideas have helped me understand the 
different modes of production and collaboration among artists and cultural producers, my main focus in this book is on the artists and their work. I do, however, acknowledge that they do not operate in a vacuum. The artistic infrastructure, as it existed and developed in the course of the decade, was formed by three elements: (1) the official art scene largely controlled by cultural and artistic state institutions; (2) the privately owned, commercial galleries; and (3) the new, independent and experimental initiatives, such as independent festivals and art spaces, workshop initiatives and other activities that do not fall into the first two categories. My work and research in Syria were strongly focused on the last category, occasionally entering into the field of commercial galleries when they claimed an interest in new artistic media and techniques - a claim not always substantiated. The interest of these galleries was clearly commercial and particularly in the case of one of the new galleries, mainly lay in the promotion of art as an investment.

Chapter 2 is focused on the artists and their perception of self as engaged social actors. I discuss the notions of "critical" and "committed" art as they were articulated by Western theorists and their translation into the Syrian context. Since the Arabic term for "committed art", al-fann al-multazim, has often been misused by authoritarian and dictatorial regimes, many artists have become wary of the term. This should always be kept in mind when discussing art of the Arab world in relation to this concept. The term "critical art" has been used in Western contexts in relation to contemporary artistic practices which include a great variety of media and often use performative and participatory approaches. While such practices have not played an important role in Syria (or in the wider Arab world), the idea of an art that challenges and questions the status quo and thereby suggests the possibility of a world with different social and political structures comes very close to the particular worldmaking project of Syrian artists. Central in much of Syrian art production, from the beginning of oil painting in the European modality to the video works of the younger generation, is a strong belief in the transformative powers of art as a space within which to imagine a different world and as a tool that can be applied to achieve change by installing a wish for this change in its audiences. I close the chapter with a brief discussion of the audiences of contemporary art works in Syria.

Chapter 3 is dedicated to the art works themselves, relating contemporary art works to works by previous generations of artists and filmmakers. I pursue four thematic lines, through which Syrian artists have voiced their criticism of social and political conditions and advocated for positive change: The first examines the issue of Palestine as caught between official ideology, the personal activism of artists and its use as a metaphor, the second takes a close look at works that address the presence of unseen threats in Syrian society through the use of metaphorical language, the third discusses works that critique particular forms of societal rigidity, such as reductive gender roles and normative behaviour; and the fourth presents an analysis of works that challenge official discourse and taboos and venture into the terrain of political critique.

In Chapter 4, I focus on the complex relations of Syrian artists and the international art world. I begin with a discussion of the increased international interest in contemporary art from the Arab world or the Middle East in the context of the globalizing art world of the 1990s and 2000s and discuss some of the problematics at play, such as essentialist representations of Arab/Middle Eastern/Muslim artists. Since Syrian artists were largely absent from many large-scale exhibitions staged in the West during the 2000s, which sought to provide a comprehensive view of artistic production in the Middle East, I examine the possible reasons for this relative under-exposure. This lack of 
visibility during the 2000s stands in stark contrast to the situation following the beginning of the uprising-turned-war in March 2011. The last section of Chapter 4 turns attention to artistic production after that date and its international reception. The uprising put an abrupt halt to the development of the art scene in Syria and prevented many promising initiatives from reaching their full potential, but also led to new forms of artistic practice that gained in importance as artists strove to articulate their positions on the political situation and advocate for peaceful change. One of the most notable was the role of the internet, which developed into a major space for artistic debates and the distribution of critical art works very soon after the beginning of the uprising. This led to an increased visibility of artists, whose works were widely shared among online communities and caught the attention of international curators and festival organizers. I close the chapter with a discussion of the complexities facing Syrian artists, who have been displaced and find themselves in environments that differ strongly from that in Syria, such as the risks of their works being fetishized as "war art" and presented through an essentializing lens. As artists attempt to come to terms with personal and collective traumas, this presents important challenges to their work and existence as artists.

This book is based on my PhD dissertation, which was written between 2012 and 2017. Sadly, the period of writing was also coincidental with Syria's descent into total disaster. Most artists who were part of my network in Syria, and whose work I discuss here, were forced to leave the country, some of them after experiences of imprisonment and violence. Those who stayed were facing extremely difficult living and working conditions. However, it would be a mistake to expect the artistic and cultural life in Damascus to have come to a complete halt, although it has lost the vibrancy that characterized it in the 2000s. The Faculty of Fine Arts at the University of Damascus remains open and each year sees new graduates. Exhibitions are still being held, but are mainly organized by people with close relations to the regime. One sad consequence of this is a certain disconnect between artists living in Syria and those outside, something that is particularly problematic for the young, recent graduates of the Faculty. As I write these words, in late 2019, Syria's future continues to appear dark. Even if fighting has decreased and the regime has celebrated the end of the war by re-opening the National Museum in Damascus in 2018, it does not change the fact that many Syrian cities are in rubble, and millions of Syrians are dead or displaced. ${ }^{18}$ During my writing, it was not always easy for me to focus on a period that seems so innocent in retrospect and yet, throughout the entire process, I was driven by the wish to ensure that the work of the young artists discussed here, much of which was so ephemeral, is not forgotten. It is my firm conviction that the creative production since 2011, and the substantial attention it has received, owe much to the work of these young people, who, with a great sense of adventure, embarked on a practice in artistic media that was at that time new to the Syrian art scene and largely unseen in the country.

\section{Notes on Transliteration and Titles}

For the sake of readability, I have chosen to limit the transcription of diacritics to "ayns" and "hamzas" in Arabic technical terms, titles and certain personal names.

For the transcription of artists' and art world professionals' names, I adopt those favoured by the artists or art professionals themselves or the most common spelling as they appear in international art publications. ${ }^{19}$ These do not always conform to standard linguistic rules, but have been chosen to facilitate further research and to make the study 
more accessible to non-Arabists and to members of the global art history community. For the names of Arab institutions, I am using their English names, if they use one, since these are generally used in international literature and the common English transcriptions. When mentioning these institutions for the first time, I provide the Arabic names as well. In the case of titles of artworks, I give both the Arabic and the English title, if they have one. Some later art works, especially those produced after artists have left Syria, do not have Arabic titles.

\section{Notes}

1 Persekian (2003), p. 96.

2 Programmes include: Positions: Experimental Short Films and Videos from Lebanon, Palestine and Syria at Casino Luxembourg, Forum d'art contemporain, City of Luxembourg, in 2008; A Silent Cinema: Highlights des syrischen Kinos at Arsenal, Institute of Film and Video Art, Berlin, in 2009, Sites of Memories: Experimental Film and Video from Syria at the Museum of Contemporary Art, Roskilde, Denmark, in 2010; So Close in the Distance: Young Arab Video Art at the European Media Art Festival, Osnabrück, Germany, in 2011 and Behind Walls: Recent Films from Syria at Arsenal, Institute of Film and Video Art, Berlin, in 2011 and the Overgaden Institute of Contemporary Art, Copenhagen, in 2012.

3 cooke (2007).

4 Wedeen (1999).

5 Boёx (2011a).

6 Lenssen (2014).

7 See Lenssen (2011) for the access policies of official art institutions in Syria. It even proved difficult, though not impossible, for me to get permission to use the library of the IFPO (Institut Français du Proche Orient).

8 Meskimmon and Rowe (2013), p. 7; Wang (2003), p. 69.

9 For a similar development in another context, namely, in South Africa, see Arnold (2013), p. 127.

10 Egan (2011a), pp. 44, 46.

11 See Chapter 2, Section 1.2.

12 Saddeka Arabi, quoted in Nashashibi (1998), p. 180.

13 Saddeka Arabi, quoted in ibid., p. 180.

14 See Adams (2005), p. 534, for a discussion of a similar problematic when writing about politically engaged folk art in Chile under the Pinochet dictatorship.

15 See cooke (2007) for a study that includes visual artists, filmmakers and writers.

16 Said (1979), p. 15.

17 Becker (1982), pp. 2-4.

18 See www.theguardian.com/world/2018/oct/28/syria-national-museum-damascus-reopeninghailed-as-return-to-normal-life (accessed 10 December 2019).

19 Joanne Lisinski, former head of research at Mathaf Museum of Modern Art, discussed the issue of the "correct" spelling of Arab artists' names at the Global Art Forum in Kuwait in 2015. Available at: www.youtube.com/watch?v=4b-rE-nh_hI (accessed 10 December 2019). 


\section{Notes}

\section{Introduction}

1 Persekian (2003), p. 96.

2 Programmes include: Positions: Experimental Short Films and Videos from Lebanon, Palestine and Syria at Casino Luxembourg, Forum d'art contemporain, City of Luxembourg, in 2008; A Silent Cinema: Highlights des syrischen Kinos at Arsenal, Institute of Film and Video Art, Berlin, in 2009, Sites of Memories: Experimental Film and Video from Syria at the Museum of Contemporary Art, Roskilde, Denmark, in 2010; So Close in the Distance: Young Arab Video Art at the European Media Art Festival, Osnabrück, Germany, in 2011 and Behind Walls: Recent Films from Syria at Arsenal, Institute of Film and Video Art, Berlin, in 2011 and the Overgaden Institute of Contemporary Art, Copenhagen, in 2012.

3 cooke (2007).

4 Wedeen (1999).

5 Boëx (2011a).

6 Lenssen (2014).

7 See Lenssen (2011) for the access policies of official art institutions in Syria. It even proved difficult, though not impossible, for me to get permission to use the library of the IFPO (Institut Français du Proche Orient).

8 Meskimmon and Rowe (2013), p. 7; Wang (2003), p. 69.

9 For a similar development in another context, namely, in South Africa, see Arnold (2013), p. 127.

10 Egan (2011a), pp. 44, 46.

11 See Chapter 2, Section 1.2.

12 Saddeka Arabi, quoted in Nashashibi (1998), p. 180.

13 Saddeka Arabi, quoted in ibid., p. 180.

14 See Adams (2005), p. 534, for a discussion of a similar problematic when writing about politically engaged folk art in Chile under the Pinochet dictatorship.

15 See cooke (2007) for a study that includes visual artists, filmmakers and writers.

16 Said (1979), p. 15.

17 Becker (1982), pp. 2-4.

18 See www.theguardian.com/world/2018/oct/28/syria-national-museum-damascus-reopeninghailed-as-return-to-normal-life (accessed 10 December 2019).

19 Joanne Lisinski, former head of research at Mathaf Museum of Modern Art, discussed the issue of the "correct" spelling of Arab artists' names at the Global Art Forum in Kuwait in 2015. Available at: www.youtube.com/watch?v=4b-rE-nh_hI (accessed 10 December 2019).

\section{Chapter 1}

1 See www.syrianobserver.com/EN/News/29839/PM_Hails_Arab_Artists_Role_War_Against_Ter rorism (accessed 10 May 2019). This is a translated, possibly abbreviated, version of the article.

2 See www.syrianobserver.com/EN/News/29839/PM_Hails_Arab_Artists_Role_War_Against_Ter rorism (accessed 10 May 2019). 
3 See www.theguardian.com/world/2011/aug/25/syria-cartoonist-ali-ferzat-beaten (accessed 10 May 2019).

4 See http://syrie.blog.lemonde.fr/2013/08/23/lartiste-yousef-abdelki-relache-apres-5-semaines-desequestration/ (accessed 10 May 2019).

5 See https://syrianobserver.com/EN/news/33340/director_mohammad_malas_detained_for_seve ral_hours.html (accessed 10 May 2019).

6 See https://hyperallergic.com/54968/syrian-sculptor-wael-kaston-killed/, www.alhayat.com/Det ails/421110 (accessed 10 May 2019).

7 There are numerous examples of how authoritarian states display their belief in the power of art. To give just one example: commenting on the censorship of one of her works by Chinese authorities, the American artist Sarah Sze said: "It was amazing to me that the Chinese government actually paid such attention. It suggests a belief that art has a major influence on society." See www.theguardian.com/artanddesign/2016/sep/11/protest-art-miro-elmgreen-dragset-isaac-juli en-sarah-sze-doug-aitken-interview?CMP=share_btn_fb (accessed 10 May 2019).

8 Lenssen (2014), p. 17.

9 For a discussion of the dilemmas of poets and writers in Ba'thist Iraq, see Tramontini (2013).

10 Lenssen (2014), p. 283.

11 Sjeklocha and Mead (1967), p. 61.

12 This ideological take on artistic production is reflected in numerous writings by Syrian critics and officials of the Ministry of Culture, see e.g. Al-Sharif (1984-1985), pp. 4-7. See also several forewords to cultural events by the Minister of Culture, Najah Al-Attar in the Syrian art journal Al-hayat al-tashkiliyya, e.g. Al-Attar (1986-1987).

13 cooke (2007), p. 30.

14 Naef (2003), p. 192; Scheid (2010), p. 211; Massad (2007), p. 16.

15 For a discussion of the term tathqif, see Scheid (2010), p. 203. See Naef (2001), p. 56, for a discussion of ideas of reforms in the social domain.

16 See Naef (2003), pp. 189-190, for a brief outline of the general changes in the visual realm of modernizing cities.

17 Scheid (2010), pp. 209-210, 218.

18 See Weber (2002), pp. 146-147, for a discussion of mural paintings in Damascene houses of depictions relating to the Paris Commune and volcanic eruptions, see pp. 65-166 and pp. 168-169 for depictions of symbols of modern life. Tariq Al-Sharif mentions that framed paintings came to replace traditional ornamentation in private homes. See Al-Sharif (1984-1985), p. 8. For a discussion of practices of wall and ceiling paintings with similar motifs in Beirut and the Levant, see Barakat (2003), p. 133.

19 Naef (2003), p. 202. Maari (2006), pp. 94-95 provides a list of early painters in Syria.

20 Naef (1996), pp. 75-76.

21 Bahnassi (1974), pp. 10, 11; Al-Sharif (1984-1985), pp. 7, 8, 13.

22 See Davidian (2014) for a discussion of Late Ottoman Armenian artists and their treatment by later Turkish and Armenian art historians. See Scheid (2010) for a discussion of early twentieth-century Lebanese painters. For a re-reading of the Egyptian ruwwad sculptor, Mahmoud Mukhtar, and his cosmopolitan social environment, as opposed to a purely nationalistic interpretation, see Radwan (2011). In relation to other non-Western artists, recent scholarship has likewise presented new interpretations of their work and highlighted hitherto neglected aspects. See e.g. Juneja (2011) and Mathur (2011) for a discussion of the Indian-Hungarian modernist artist, Amrita Sher-Gil.

23 Radwan (2011), p. 60.

24 Scheid (2010), pp. 216-218.

25 Qashlan (2006), p. 18. The biographical data available for this painter is scarce, often conflicting and largely anecdotal. See Bank (2016b) for a discussion of this research problem and a discussion of some of his works. For biographical data, see Qashlan (2006), pp. 14-20; Al-Sharif (1984-1985), pp. 14-16; Atassi (1998), p. 65; Ali (1997), p. 87.

26 Al-Sharif (1984-1985), p. 14. Oil painting was taught in Ottoman military primary and secondary schools for military purposes, but despite this utilitarian aspect, it seems that some well-known Ottoman artists taught in such schools See Shaw (2011), p. 31 for information on art education in Ottoman schools. 
27 Tareq Al-Sharif mentions this "influence" but does not further elaborate on how this is manifested, see Al-Sharif (1984-1985), p. 14.

28 Lenssen (2014), p. 24; Hussam al-Din and Abu Ayash (1991), p. 44. Aivazovsky appears to have been invited to Istanbul on several occasions between 1857 and 1890. Unfortunately, not much is known about these early years of Tawfiq Tarek's training and much remains subject to speculation.

29 See Bank (2016b), for a discussion of the element of critique in the works of Tawfiq Tarek.

30 The painting is now in the Musée d'Orsay in Paris: See www.musee-orsay.fr/fr/collections/ca talogue-des-oeuvres/notice.html?no_cache $=1 \&$ nnumid $=001462 \& \mathrm{cHash}=\mathrm{e} 54 \mathrm{f} 2 \mathrm{~d} 6635$ (accessed 10 May 2019). Unfortunately, the exact circumstances of how and when Tarek had access to Bouchard's painting are not known.

31 See Bank (2016b). See also Naef (2002), pp. 225-226, for a brief discussion of the painting.

32 One proponent of these ideas was the Syrian intellectual and activist Muhammad Kurd Ali (1876-1953), who participated in several of the International Congresses of Orientalists and was a fervent critic of much European Orientalist scholarship, see Escovitz (1983), pp. 97, 106. See also Ende (1984), p. 70. In Arab painting, such ideas are reflected in what is occasionally referred to as "classicist" art by Arab art historians. The term "classicist" is somewhat misleading here, since it does not, as in European art history, designate an intellectual, cultural and artistic movement that turned towards Graeco-Roman antiquity for inspiration. However, the turn towards the past for inspiration and examples of moral grandness is common to both movements. See Al-Sharif (1984-1985), p. 10.

33 Unfortunately, the exact dimensions of the painting are not known and it remains entirely inaccessible, as it is located in the Presidential Palace in Damascus. Likewise, images of this painting are extremely rare. A reproduction of poor quality is depicted in Hussam al-Din and Abu Ayash (1988), Figure 6.

34 For a discussion of history painting as moral lessons, see e.g. Conn (2002), pp. 23-25.

35 "Saladin, here we are!"

36 Ende (1984), p. 89.

37 Saladin and the motif of Hittin have undergone a number of ideological transformations in the course of Syrian history. Under the rule of the Ba'ath Party and after Hafiz al-Assad had established his authoritarian regime, Saladin and the motif of Hittin gained in importance as a symbol of Arab victory over the imperialist forces and, interestingly, Hafiz al-Assad became closely linked to the person of Saladin. A parallel was even drawn between the latter's victory at Hittin and al-Assad "victory" in the October 1973 war. During a symposium in Damascus in July 1987, held to celebrate the 800th anniversary of Saladin's victory over the Crusaders at Hittin, Najah al-'Attar, then Minister of Culture, said: "The soil which has born Saladin is the same soil that has produced Jamal 'Abd al-Nasir and Hafiz al-Asad, who came to complete the mission of "Abd al-Nasir by liberating, unifying and awakening the Arabs to prepare them for the battle" (cited in Freitag 1999, p. 11). The importance of the figure of Saladin for the Syrian regime can also be seen in the recent statue of Saladin by 'Abdallah al-Sayyid, erected in front of the citadel in Damascus in 1992. See also Wedeen (1999), p. 3.

38 For a discussion of a similar phenomenon in Ottoman modern painting, see Shaw (2011), p. 3.

39 For a discussion of the political dimensions of modern painting in Syria in its international context, see Lenssen (2014), pp. 38-49.

40 Ibid., p. 13.

41 See, for instance, Naef (2003), p. 189; Naef (1996), pp. 13-15.

42 Qashlan (2006), p. 17. Unfortunately, information on such activities are very scarce and the few available sources only provide very few details. However, they are generally viewed as being particularly important for the development of modern art in the Arab world, see Zayat (2008), p. 19, for a statement about this aspect of artists' activities.

43 Lenssen, Rogers, and Shabout (2018), pp. 104-106. Translation from French by Kareem James Abu-Zeid.

44 Ibid., p. 88.

45 Bardaouil (2016), p. 18. For a discussion of the group, see also Naef (1996), p. 82.

46 Lenssen, Rogers, and Shabout (2018), pp. 94-95. See also Bardaouil (2016), pp. 34-35.

47 LaCoss (2010), p. 103, see pp. 83-84, for a discussion of the group's activities.

48 Sjeklocha and Mead (1967), p. 61. 
49 Sjeklocha and Mead (1967), p. 61

50 In the case of Tawfiq Tarek, his choice of Paris was less voluntary, but rather prompted by the necessity to seek asylum in France in 1895, after having been briefly imprisoned in Istanbul. While Syrian artists needed to rely on their own financial resources to study in Europe, students at the School of Fine Arts in Cairo profited from a system of scholarships that sent selected ones to Europe, see Radwan (2011).

51 Lenssen (2014), p. 23.

52 For a discussion of the training opportunities for artists in Syria in the twentieth century, see Bank (2019b). For a history of the institute, see Avez (1993).

53 Ibid., p. 27.

54 Shabout (2007), p. 20; Al-Sharif (1984-1985), p. 10; Avez (1993), p. 38; Dussaud (1927), pp. 248-253.

55 Members included Mahmoud Hammad, Adham Ismail, Adnan Jabasini, Nasir Shoura, Salah al-Nashef, Rashad Qusaibati, and Mahmoud Jalal. See Lenssen (2014), p. 30.

56 Ibid., pp. 30-35.

57 Bahnassi (1974), p. 1 (my translation).

58 Lenssen (2017), p. 223.

59 Lenssen (2014), pp. 218, 286.

60 The UAR lasted from 1958-1961.

61 On the website of the organization, the name given in English is "National Film Organization". However, the article on the page "Organization History" gives the name as "General Cinema Organization", which is closer to the Arabic. In the English language literature, however, "National Film Organization" is more commonly used and, for this reason, I am using this term here.

62 For a history of the NFO, see Boëx (2011a), p. 113.

63 Ibid., pp. 78-79.

64 Ibid., pp. 115-116. My translation.

65 Ibid., p. 85.

66 Ibid., p. 36.

67 Ibid., pp. 110-111.

68 Lenssen (2014), p. 17.

69 See Winegar (2006), pp. 187-188, for a discussion of the need not to assume that all art worlds necessarily aspire for autonomy as defined by European Modernism.

70 Al Khatib and Yazaji (2010), p. 182. See also Boëx (2006), $\mathbb{\$} 4$.

71 Lenssen (2014), pp. 282-283, 302.

72 cooke (2007), p. 29.

73 Lenssen (2014), pp. 314-320.

74 Ibid., p. 321.

75 Bahnassi (1974), p. 21. See Boëx (2011b), pp. 141-142, for similar views on the role of cinema.

76 Hafiz al-Asad wa waqadaya al-kitaba wa al-kuttab (Hafiz al-Assad and issues concerning writing and writers), Damascus: Arab Writers Union Publications 1978, cited in cooke (2007), p. 25.

77 Boёx (2011a), p. 74.

78 cooke (2007), p. 8 .

79 Ibid., pp. 8-9. For a discussion of censorship in the musalsal (TV drama series) industry, see Salamandra (2015), p. 43.

80 Delphine Leccas, former head of cultural programming at the Centre Culturel Français. Conversation with author, Damascus, April 2010, email correspondence January 2013. See also Lenssen (2011), p. 2.

81 Several artists, particularly filmmakers, to whom I spoke, could tell such stories, if not from their own experiences then from those of other artist friends.

82 Komaromi (2007), pp. 614-615.

83 Johnson (1993), p. 5.

84 Ghadbian (2001), p. 76.

85 Plesu (1995), p. 62.

86 Said (1994), p. 11.

87 Cited in Porteous (1995), p. 209. Similar thoughts were also often expressed in personal conversations I had with Malas.

88 Freitag (1999), p. 10. 
89 Massad (2007), pp. 351-354, 373-375.

90 Most literature on art production in authoritarian contexts touches upon this central topic; for examples, see Calirman (2012), pp. 2-3; Wallach (1991), p. 76; cooke (2007), p. 20; Wedeen (1999), p. 110.

91 Wallach (1991), p. 76. See Sjeklocha and Mead (1967), p. 45 on the law of "kritika i samokritika" (criticism and self-criticism), which should guide an artist to know what to paint and what not to paint. See also Devictor (2002), pp. 67-68, for a discussion of the lack of clear rules of censorship in relation to cinema in early post-revolutionary Iran.

92 cooke (2007), p. 26; Devictor (2002), p. 70; Komaromi (2007), p. 614; Naficy (2002), p. 50; Salamandra (2015), p. 43; Wallach (1991), p. 76.

93 Plesu (1995), p. 64.

94 cooke (2007), pp. 19-20.

95 Ibid., pp. 29-30.

96 Ibid., pp. 72-74.

97 Similar practices can be found in Iran. See Egan (2011a), p. 44, for examples from the Pahlavi era and pp. 52-53 for the post-revolutionary era.

98 Boëx (2011b), p. 149.

99 cooke (2007), pp. 102, 106. Such screenings were, however, rare and most of the time Syrian films of this kind remained firmly locked up in the archives of the National Film Organization.

100 I heard such stories from a great number of people involved in film production, both filmmakers and independent producers.

101 Cited and translated in Boëx (2011a), p. 290.

102 cooke (2007), p. 31.

103 Filming these scenes involved taking some substantial risks, since Syrian films (and TV series) are normally filmed on location rather than in a studio. Thus, filming these scenes necessitated taking down actual posters of Hafiz al-Assad and replacing them with the fictional ones. In the case of this particular film, the film crew working on the set was also employed by the Mukhabarat (intelligence service), but appear to have been sympathetic to the filmmaker's project. This may explain why it was possible to take down official posters and banners in the first place, but it also illustrates the conflict-laden climate, within which filmmakers were working. Oussama Mohammad was obliged to rely on the whims of the regime in order to produce a film that was critical of that very regime. See Wedeen (1999), p. 115.

104 For a discussion of the family as a metaphor in official ideology, see ibid., pp. 49-66.

105 Ibid., p. 3.

106 I have not been able to gain any information concerning the transfer of this painting to the present location in the presidential palace, nor whether it is actually still located there.

107 Perthes (2004a), p. 13; Perthes (2004b), p. 103.

108 Literature that discusses different aspects of the "Damascus Spring" movement is quite abundant. See e.g. Pace and Landis (2012), pp. 120-122.

109 "Statement by 99 Syrian Intellectuals", originally published in Al-Hayat on 27 September 2000, translation from the original Arabic by Suha Mawlawi Kayal. Available at: www. meforum.org/meib/articles/0010_sdoc0927.htm (accessed 15 May 2019).

110 For a timetable of events of the "Damascus Spring", see Perthes (2004a), pp. 15-19.

111 Wedeen (1999), p. 87.

112 Salamandra and Stenberg (2015), p. 2.

113 Personal communication by an anonymous activist, Damascus, June 2009.

114 Hinnebusch (2012), p. 104; Salamandra and Stenberg (2015), pp. 8-9.

115 Ibid., p. 6.

116 Cited in Salti (2006), p. 51.

117 I thank Delphine Leccas for pointing out these aspects of the official art scene to me.

118 This was deplored by several younger artists with whom I spoke.

119 For an idea of the activities of the Journées de la photographie, see www.delphineleccas.org/ section300500.html

120 Perthes (2004a), p. 11.

121 See Efimova (1997), pp. 76-77, for a description of the philosophical and aesthetic discussions surrounding the adaptation of Socialist Realism. It is commonly understood that Socialist 
Realism was adopted as the official style of Soviet art and literature at the First Congress of Soviet Writers in 1934 and prevailed as the governing principle of art and literature until the mid-1980s. However, it was not formulated as a monolithic set of rules for artists and writers to apply in their practice and left room for individual interpretation, something that also made artists vulnerable to accusations of deviation from official ideology. This vulnerability has certain parallels with the lack of clear rules imposed by censorship discussed above.

122 Komaromi (2007), p. 626.

123 Abir and Nisrine Boukhari, conversation with author, Damascus, April 2009.

124 All Art Now (2008), p. 5.

125 To get an idea of these festivals, see www.allartnow.com/living-spaces-festival.php (accessed 10 December 2019).

126 The company relocated to Cairo after the arrest of Nyrabia in 2012 and subsequently to Berlin, where it is now based.

127 Diana El-Jeiroudi and Orwa Nyrabia, conversation with author, Damascus, June 2009.

128 This critique was voiced by several people in Beirut as well as in Damascus.

129 Hegasy (2010), pp. 23, 31. See also Wedeen (1999), p. 87.

130 See www.delphineleccas.org/section442397_475618.html (accessed 10 September, 2019). I participated in the programming as curator of an exhibition of video installations. What was originally planned to become an annual or bi-annual event was re-planned as an itinerant festival by Delphine Leccas and myself and went on to be hosted by different institutions in the Netherlands (International Film Festival Rotterdam in 2012), Turkey (DEPO in Istanbul in 2013) and Germany (ZKM, Centre for Art and Media in Karlsruhe in 2014). The 2014 festival was the final one.

131 See Takieddine (2010) for a summary of this conference and some of the discussions it opened.

132 Rafia Kodmani, conversation via Skype, 12 December 2017. Kodmani expressed her sadness at having lost the centre of her professional activities and the difficulties of continuing her work in Dubai.

133 For an interview with the gallery owner, see Maghribi (2011), pp. 74-77.

134 Important critique was expressed by Youssef Abdelké upon ending his collaboration with the gallery. Available at: www.reuters.com/article/syria-art-idAFLDE6961JG20101013 (accessed 10 October 2019).

135 See www.nytimes.com/2010/11/27/arts/27iht-scdamascus.html (accessed 10 October 2019).

136 Khaled Samawi in Ayyam (2008), p. 5.

137 See www.ayyamgallery.com/news/39/info (accessed 10 October 2019).

138 Conversation with Myriam Jakiche, then the manager of Ayyam Gallery Damascus, October 2007.

139 Lenssen (2014), p. 40. See also www.reuters.com/article/syria-art-idAFLDE6961JG20101013 (accessed 10 October 2019).

140 The gallery and its practices generated much talk in artistic circles in Damascus and certain rumours of financial dishonesty, such as money laundering, were circulating about Ayyam and another, commercial gallery, Art House. See Boëx (2011a), p. 104.

141 Issa Touma, conversation with author, Aleppo, November 2007. Harsh critique of the established art scene in Syria was voiced by Issa Touma in several conversations.

142 For claims of interest in young talent, mostly expressed to international media, see www.da ilystar.com.lb//Culture/Art/2006/Sep-15/114023-issa-touma-vs-the-syrian-state.ashx\#axzz2Hlw rP2Qb (accessed 10 October 2019). Several young artists with whom I spoke in Damascus expressed their disappointment at Issa Touma's neglect of their work.

143 Becker (1982), p. 162.

144 Ibid., p. 304.

145 Bourdieu (1993), p. 42.

146 See Takieddine (2010), pp. 60-61 for a summary of this critique. See Keiso (2006) (unpaginated) for mention of similar views among Arab audiences. See Winegar (2006), pp. 158-172, for a discussion of similar debates going on in Cairo.

147 Bourdieu (1993), p. 42.

148 Anonymous audience member, cited in Takieddine (2010), p. 60.

149 Amiralay (2009). Despite the somewhat patronizing views expressed in this filmed interview, Amiralay was one of the most active people in Syria in his encouragement of the young independent film and video scene. 
150 Salamandra (2004), p. 147 and Salamandra (2008), p. 188. See also Winegar (2006), p. 295, for a discussion of a climate of competition among Egyptian artists seeking exhibition opportunities in the expanding private gallery scene of Cairo in the early 2000s.

\section{Chapter 2}

1 cooke (2007), p. 115. See also a report by the UN Refugee Agency, dating from 18 June 2009: Available at: www.refworld.org/docid/4a5f30272d.html (accessed 10 October 2019).

2 Cited in Preda (2012), p. 900.

3 Cited in Danko (2011), p. 49.

4 Smith (2011), pp. 174-175. Italics in original.

5 Meskimmon (2011), pp. 191-192. Italics in original.

6 Wedeen (1999), p. 89.

7 She made this observation during her fieldwork among Syrian TV makers. See Salamandra (2008), p. 180.

8 Buthayna Ali, conversation with author, Damascus, October 2010.

9 Artists such as Francisco Goya and Hans Holbein come to mind with their strong outspokenness against the brutality of war.

10 Clark (1973), p. 9. Despite this, art history has often been reluctant to discuss the political dimension of art works. A striking example is Gustave Courbet, who was deeply involved with socialist politics, recognized by critics as a socialist artist and served as the position of director of art affairs during the Paris Commune of 1870-1871, yet underwent a posthumous process of "de-politicization" to make his art more palatable for the art market and its conservative public. See Nochlin (1982). For a discussion of Courbet's political affiliation, especially to the socialist philosopher Pierre-Joseph Proudhon, see Crapo (1991).

11 "The literature is embedded in its era, thus it is a mirror; the writer is committed, thus he is an active player", Ory and Sirinelli (1986), pp. 147, 149. See also Bourdieu (1993), p. 54.

12 Sartre (1993), p. 177.

13 Ibid., p. 224.

14 Ibid., pp. 220-221.

15 For a summary of the activities of the group and the discussions their work and writing inspired, see LaCoss (2010). For translations of the articles and critiques as well as the group's manifesto "Long Live Degenerate Art", see Lenssen, Rogers and Shabout (2018), pp. $87-105$.

16 Klemm (2000), p. 51.

17 Ibid., p. 57.

18 Quoted in Massad (2007), p. 139.

19 See Lenssen (2013), p. 64 and Lenssen (2014), pp. 327-329.

20 See Naef (1996), pp. 100-106. See also Bardaouil and Fellrath (2016), pp. 149-167.

21 Mamdouh Adwan, cited in cooke (2007), p. 91.

22 Boёx (2006), $\$ 16$.

23 See Kayali (2008). Unfortunately, the text I refer to here is reprinted from a non-disclosed source and is undated. Therefore, the original context of this opinion remains unknown.

24 Youssef Abdelké, conversation with author, April 2014.

25 See also Bank (2018b) for a discussion of the problematic of translating terms related to the social engagement of artists.

26 Björn Luley, conversation with author, September 2009.

27 Such negotiations are sometimes dismissed as a "selling out" of one's ideals. But I would argue that it is important not to condemn all cases of working with certain elements of the state, as it might occasionally represent an important way to achieve valuable results, however small they might be. See also Hegasy (2010), p. 31.

28 Wedeen (1999), p. 87. See also Scott (1990), p. 212. In a similar vein, referring to the GDR, Ulrich Dormröse noted that photography, like literature, film, theatre, fine art and rock music, "took over a substitute-function for a missing discourse about the increasingly obvious difference between social reality and political pseudo reality”, Dormröse (2012), p. 16.

29 Wedeen (1999), p. 150. 
30 Anonymous artist, conversation with author, July 2007. It is interesting that this artist chose to see former generations of artists as more radical in their advocacy for change and disregard the careful weighing of means of expression in the works of older artists.

31 Salamandra and Stenberg (2015), p. 3.

32 Smith (2011), pp. 174-175. Smith places this concern in opposition to the art of the Modernist era.

33 Ibid., p. 176.

34 Ibid., pp. 184-185.

35 Meskimmon (2011), p. 192.

36 Ibid., p. 192.

37 Wang (2003), p. 69.

38 Maleh (2006), pp. 92, 94. The text is a translation of the earlier text that appeared under the title Mashahed min al-hayat wa al-sinema, published in 'Alam al-Fikr, a journal of the Kuwait National Council for Culture, Arts and Literature in 1997.

39 Ibid., p. 94.

40 The remark "art history as we learn it stops with Picasso" was a kind of standard joke among the young artists I talked to.

41 Even those professors, who were open to contemporary media, emphasized that, since such practices were not part of the curriculum, there was hardly any time for serious treatment of them. Buthayna Ali, an artist and professor at the Faculty of Fine Arts of Damascus University, whose own artistic practice often included large-scale installations, told me that she made a point of mentioning contemporary methods and suggesting further individual research to her students, but that the tight schedule of her courses did not allow any detailed discussion of aesthetics and approaches, Buthayna Ali, conversation with author, Damascus, April 2010. Concerning the general lack of support for new modes of expression, I should note that I did not conduct a systematic survey among art professors, critics and organizers of the official art and culture circuit while I was in Syria, and later, the situation in the country no longer permitted me to travel there and conduct further research. For this reason, I cannot provide a qualified view on this issue.

42 These were misgivings expressed to me in conversations with a number of young artists.

43 Toukan (2015), p. 336.

44 Here it is significant to note the almost total absence of pieces of video art or installation art at official exhibitions. One exception was an exhibition focused on the young artistic generation which was part of the retrospective of visual art in Syria organized as part of the Damascus Arab Capital of Culture festivities in 2008. The retrospective was curated by Delphine Leccas, former head of cultural programming at the Centre Culturel Français. Leccas was well acquainted with the work of young video and installation artists and it was probably thanks to her that they were included in the programme.

45 Workshops were welcomed as valuable opportunities to gain first-hand knowledge from established artists, but they were irregular and the results often suffered from the lack of thorough and long-term commitment, which is inherent in this training model. The common practice of inviting a well-known European artist to conduct a workshop and afterwards exhibit alongside young, inexperienced Syrian artists was criticized on several occasions, as it was seen as presenting a distorted image of the Syrian art scene. Indeed, the practice does run the risk of conveying the unfortunate idea of an underdeveloped local scene in need of guidance from the more sophisticated European art world. Thereby, the agency of local artists might easily be overlooked. However, this issue is more related to European cultural policies than the contemporary art scene in Syria and is not the subject of the present study. In the first part of the decade, a young self-taught videomaker, 'Ala Arabi Katbi, set up a video atelier to promote digital media and offer basic technical and theoretical training. He was able to get some professional film and TV directors on board who offered workshops for young aspiring videomakers. However, due to financial constraints and lack of useful institutional contacts, he was obliged to abandon the project after some years. See Boëx (2006), \$21-23.

46 Amiralay (2006), p. 97.

47 Ibid., pp. 97-98.

48 Ibid., p. 98.

49 Amiralay (2009) (filmed dialogue). 
50 The AIF was established together with the Lebanese-American filmmaker Hisham Bizri, the Egyptian filmmaker Hala Galal and three teachers from the Danish National Film School, Jesper Højbjerg, Jakob Høgel and Anders Østergaard. Funding came from the Danish NGO, IMS (International Media Support).

51 Salamandra (2008), p. 177.

52 Ibid., p. 179. This was not without risks on the artistic level, as commercial work risk influencing the artistic work and making it unsuitable for the art world. Howard Becker mentions the example of photographers who do commercial work as well as artistic work and complain that commercial attitudes have found their way into their art, "making it hard for them to see and photograph in a way that does not embody the restraints of the advertising mentality", see Becker (1982), p. 96.

53 These only began to develop in the second part of the decade, but despite the undeniable promises they held, the uprising and war of the 2010s put an end to their activities and they were never allowed to flourish.

54 See Boëx (2006), $\$ 19$.

55 Christie's inaugurated annual auctions in Dubai in 2006, Sotheby's followed in 2008 with auctions in Doha and Bonham's held auctions in Dubai in the same year: www.art-finance. com/AA_Nov_2012.pdf (accessed 10 October 2019).

56 To get an idea of the installation Tent, which was presented in the courtyard of the National Museum in Damascus, see www.buthaynaali.com/alkhema.htm (accessed 10 December, 2019).

57 Marks (2003), p. 43.

58 See Marks (2000), p. 6 for a discussion of the term "cinema", which she prefers in her discussion of intercultural, experimental work, whether shot on video, $35 \mathrm{~mm}$, or other formats.

59 See Salloum (2005), pp. 28-29; Hadria (2005), p. 33; Keiso (2006), unpaginated.

60 Marks (2015), p. 2.

61 Ammar Al-Beik, conversation with author, Damascus, November 2007.

62 Alkassim (2004), p. 6.

63 The fact that these films are unauthorized copies of copyright material does not constitute a criminal offence in Syria, as the country has not signed international copyright agreements. However, these films were not normally screened in Syrian cinemas and would therefore not have received the green light from the censors. The informal market for pirated DVDs therefore constituted a tolerated, grey area of semi-illegality.

64 Rosler (1990), pp. 31-33. It is interesting to note that video as an artistic medium came to Syria as a digital medium. VHS had no importance in the Syrian art scene and I do not know of any artists who experimented with it. Its popular use, e.g., to commemorate important family festivities such as weddings, is much older.

65 See Alberro (2009), pp. 3-4.

66 See Boëx (2006), \$14.

67 See ibid., $\$ 20$. The stress placed here on the affordability of video equipment for young Syrian artists is somewhat contradicted by observations by Samirah Alkassim, who sees the costs involved in the acquisition of video equipment and technology as a significant deterrent, placing it out of reach for the majority of artists in Egypt, see Alkassim (2006), pp. 140-141. The reason for such diversity in opinions may lie in the fact that the costs of acquisition of video equipment fell significantly in the course of the decade. But a certain possible difference between the two locations notwithstanding, it is important to note that the majority of artists in the Arab world belong to the privileged strata of society, whose financial situation makes such investments imaginable.

68 Marks (2003), p. 44.

69 For example, the association All Art Now could have developed into a kind of catalyst.

70 Marks (2000), p. 20.

71 Rami Farah, artist talk at symposium "Resistance. Continuing Traditions of Satire, Art and the Struggle for Freedom", organized by DCCD (Danish Centre for Culture and Development) and Rundetaarn Exhibition Space in Copenhagen, Denmark, March 2013.

72 Quoted in cooke (2007), p. 155.

73 Dressler (2010), p. 51. 
74 cooke (2007), p. 119. That there was a certain truth in this statement was confirmed to me during the film programme I curated for the Arsenal Institute of Film and Video Art in Berlin in 2009. After one of the screenings, I was approached by a young Syrian student who told me about his immense pleasure at finally seeing those famous, controversial films whose daring critique he knew of and admired, but which he had in fact never seen.

75 Ibid., p. 119.

76 Boёx (2006), $\$ 12$.

77 See Nashashibi (1998), pp. 165-166. The debates about a particular aesthetic rooted in a cultural and/or national identity have given rise to heated discussions among artists and critics in the Arab world. See e.g., Scheid (2005), pp. 31-32, 41 and Winegar (2006), pp. 96-127.

\section{Chapter 3}

1 Smith (2006), p. 686.

2 Here one should perhaps mention that most Syrians became quite adept at recognizing agents of the Mukhabarat (secret police). This is echoed in the remark of one of the characters in Nabil Maleh's Al-kompars (The Extras), who says about a secret service agent: "People like those have their ID's ... stamped on their faces", cited in Gugler (2011), p. 127.

3 I am loosely adapting the concept of a "rhizome" as it was developed by Gilles Deleuze and Félix Guattari in Mille Plateaux (A Thousand Plateaus) to describe a concept of knowledge formation that resists hierarchical structures and allows for multiple starting points and lines of thought, see Deleuze and Guattari (2013), pp. 1-27.

4 See also Boëx (2011a), pp. 245-247, for a discussion of this film.

5 See e.g., cooke (2007), pp. 6-8; Perthes (2004), p. 106.

6 Mukhayyam al-Yarmouk, the large Palestinian refugee camp in Damascus, its administrative status being a city in the governorate of Damascus. With its architecture that more resembled popular, working-class districts, Yarmouk appeared more like a popular quarter than a "camp". The camp became heavily involved in fighting between various factions of the Syrian Civil War from 2012 onwards and large parts were destroyed, leaving it in the state of a ghost town in 2015 after it was overrun by militants of ISIS.

7 Anonymous artists, conversation with author, May 2008.

8 See www.buthaynaali.com/I_am_ashamed.htm (accessed 15 November 2019).

9 Buthayna Ali, conversation with author, Damascus, April 2010.

10 Ali (2009), see also www.buthaynaali.com/I_am_ashamed.htm.

11 Buthayna Ali, conversation with author, Damascus, April 2010.

12 For a theoretical discussion of the concept, see Campbell (2004), pp. 61-62.

13 See ibid., pp. 61-62.

14 Sontag (2003), pp. 101-102. See also Bank (2019a), pp. 136-137, for a discussion of the effects of "viral" images in the context of the Syrian uprising and war.

15 Campbell (2004),p. 71.

16 Sontag (2003), p. 118.

17 Lenssen (2013), p. 63.

18 Salti (2006), p. 30.

19 Cecile Boëx sees these films as straightforward examples of radical cinema (Boëx, 2011a, pp. 77-78). However, the example of Alaouie's film demonstrates that critique on several levels was also present in these early films. Thus, Alaouie's film also criticizes a general lack of social coherence and willingness to organize around a common cause. For example, an attempt to organize a strike to force an increase in pay fails due to selfishness and corruption and opportunism create a general sense of hopelessness and stagnation.

20 In the catalogue of the Samawi collection, which holds the painting, the title is given as The Refugees, Ayyam (2011), p. 17. Anneka Lenssen, who has done extensive research on the artist and his work, gives the title Family of Refugees in Abu Rummaneh Street, Lenssen (2014; 2017).

21 Lenssen (2014), p. 69; Lenssen (2017), p. 226. There seems to be conflicting information about the dating of this painting. It is currently held in the collection of Khaled Samawi, the owner of the Ayyam Gallery. In the catalogue The Samawi Collection: Curated Selections of Arab Art, vol. 1, published by the Ayyam Gallery in 2011 on the occasion of the exhibition The 
Samawi Collection at the Ayyam Art Center in Dubai, the date provided is 1960, see Ayyam (2011), p. 17. Anneka Lenssen gives the early date of 1950 together with the information that it was submitted to the first national exhibition of art of that year. Boutros Maari gives the date of 1949 and mentions a reference to a review that defines the painting as "the first Arab painting of the Nakba in an expressionist style different from the usual manner of other artists who paint torn tents, barbed wire and desolate landscapes", Maari (2006), p. 1.

22 Palestinian art abounds with such motifs. See e.g., Boullata (2009), pp. 172, 257.

23 Louay Kayali, cited in Maari (2006), pp. 186-187.

24 "Nakba" meaning "catastrophe" is the common designation in Arabic for the war of 19481949 that led to the creation of the state of Israel and the expulsion of more than 700,000 Palestinians, see e.g., Takkenberg (2010).

25 Ankori (2006), p. 49.

26 Boullata (2009), p. 132.

27 As a Palestinian friend emphasized, cheap reproductions of such paintings were common items of decoration in simple Palestinian homes.

28 See Lenssen (2017), for a discussion of the painter's work and his search for a specific Arab aesthetic.

29 See Ayyam (2011), p. 21 for an image of the painting.

30 See Lenssen (2014), pp. 323-326, for a discussion of Nazir Nabaa's works of this period. For images of a selection of his posters, see the website of The Palestine Poster Project: http://pa lestineposterproject.org/search/site/nabaa

31 Lenssen (2014), pp. 323-324.

32 See also Bank (2014), p. 1, for a discussion of this painting.

33 Personal statement by Marwan in a conversation with author, January 2015.

34 As related to me in an interview, the fate of the Palestinians remained an important concern for Marwan. Apart from his paintings of young Palestinians, he has often expressed a profound sympathy for the struggle for a Palestinian homeland, not limiting his commitment to paintings or declarations. Thus, in 1997, he dedicated a collection of paintings to a future Palestinian National Museum in the hope that a Palestinian state in which art and culture had its recognized role would come into existence. And as the director of the Summer Academy of the Darat al Funun/Khaled Shoman Foundation (1999-2003), he always made sure that the largest number of available places were reserved for Palestinian students. See also Marwan (1998).

35 Interview with Burhan Karkutli, in Karkutli (1981), unpaginated.

36 That is, "Graphics of the Revolution. Burhan Karkutli. A Palestinian Artist".

37 Cf. obituary by Georg Baltissen in the Tageszeitung: www.taz.de/1/archiv/?dig=2004/01/02/a 0150 (accessed 10 November 2019).

38 For an image of this drawing, see an essay by Burhan Karkutli, available at: www.ipk-bonn. de/kultur/news/2013041100.html (accessed 10 December, 2019). For a discussion of the figure of a young woman as a personification of the homeland in the works of Palestinian artists, see Ankori (2006), pp. 61-65.

39 It is also one of Karkutli's most widely used images, appearing in different formats with different titles. This can at times be confusing, but echoes well the artist's understanding of an uncomplicated art that was accessible to everyone. Karkutli also seems to have regarded his drawings as a kind of open well of images made to be used and reused for different purposes related to the Palestinian cause.

40 "Viva la revolución. Grafiken aus Mexico", in Karkutli (1981).

41 PLO (1978), pp. 103-108. I have listed the names here as they are written in this catalogue, even though this might not correspond to the way the names are commonly spelled in writings on international art.

42 See also Wedeen (1999), pp. 113-116.

43 See the artist's website for views of the entire series: http://hrairsarkissian.com/work/execu tion-squares/ (accessed 15 November 2019).

44 Sarkissian (2011), pp. 349-350.

45 Gugler (2011), p. 130.

46 Cited in Maari (2006), p. 365.

47 Fateh Al- Moudarres, cited in Arabi (1995), p. 25. 
48 Connelly (2012), p. 8.

49 Ibid., p. 5.

50 Ibid., p. 8.

51 Connelly (2012), pp. 12, 15.

52 Ibid., p. 18.

53 Fuss (2001), pp. 12-14. Also mentioned in Connelly (2012), p. 22.

54 See ibid., p. 107, for a discussion of the use of carnival masks in the work of James Ensor.

55 Cited in Muhanna (2008), p. 47.

56 Maari (2006), p. 363.

57 On several occasions when the work has been part of video and film programs I have curated in Europe (Denmark, Germany, Italy, Switzerland and the Netherlands), the European audiences have often been surprised at the discussions' level of openness and the in-film audience's ease with the situation.

58 Soudade Kaadan, personal statement during a Q\&A session moderated by the author at International Film Festival, Rotterdam, February 2012.

59 Soudade Kaadan, conversation with author, Damascus, September 2009. The respectful presentation of the youths was a major concern for the artist.

60 The video was realized during a training programme at the Arab Institute of Film in Amman under the supervision of Omar Amiralay.

61 The literature on so-called "honour killings" is vast and discussing the subject in detail exceeds the scope of this study. While the use of the term is debated, it is used to describe murder of a woman for sexual transgressions by members of her family, usually a brother, father, cousin, paternal uncle or husband, most often, who plan and commit the crime together. The killing is seen as a way to restore the honour to the family, who lost it due to the deviant behaviour of one of their female members. Central points of critique of the use of the term is its essentialism, as it leaves no room for differences in how communities define the concept of "honour" and its easy appropriation by mainstream media and right-wing political players, which often serves as an excuse to express Islamophobic sentiments. For a discussion on the appropriateness of the term and its definitions, see Terman (2010).

62 Preda (2012), pp. 901, 903.

63 Alkassim (2004), p. 6.

64 Hazem Alhamwi, artist talk moderated by the author, International Film Festival, Rotterdam, February 2012.

65 The film was inspired by a small note in a newspaper about an instance of "honour killing". Conversation with author, October 2010.

66 See Lenssen (2014), p. 246.

67 See ibid. p. 248 and pp. 258-259.

68 El-Jeiroudi (2005), p. 40.

69 See also Bank (2008). The video has received considerable attention outside of Syria. It was presented at an exhibition project entitled "Some Stories" at the Kunsthalle Wien in 2005, and after that has been shown at other exhibitions and at numerous festivals and curated film and video programmes in the USA, Asia and Europe. In Syria, it has received considerably less attention. It was presented at the Women's Arts Festival in Aleppo in 2005 and at the Goethe Institute in 2007 during a programme which showed short films by German film school graduates together with works by young Syrian artists and filmmakers.

70 Sparre (2008), pp. 7-9.

71 The term "state feminism" describes state policies aim at encouraging women's education and participation in the workforce. In Syria, the policies of "state feminism" also included measures to facilitate the participation of mothers in working life, e.g., by providing maternity leave, time for nursing mothers to breastfeed their babies and the establishment of day-care facilities in state-owned workplaces. See Wedeen (1999), p. 191, note 83, for a discussion of the concept. For changes in state policies towards educated women, see Sparre (2008), pp. 8-10.

72 For an interview with Diana El-Jeiroudi about this video, see https://cinemawithoutborders. com/1327-diana-el-jeiroudi-talks-about-veiled-barbie-dolls/ (accessed 15 November 2019).

73 See Bank (2020) for a detailed discussion of the following three works by Nisrine Boukhari and Buthayna Ali. 
74 Presented as part of the visual arts exhibition programme at the "Damascus Arab Capital of Culture" event in 2008. The title is a word play on the French words "peu" ("a little") and "peur" ("fear"). "Un peu rouge" can be translated as "a little flushed" or "slightly embarrassed or excited". Thus, it conveys an idea of excitement combined with fear of the unknown.

75 Presented at the group exhibition "Magnetism" at All Art Now, www.allartnow.com/ma gnetism.php (accessed 10 November 2019).

76 English translation on the website of the artist: http://nisrineboukhari.com/picture-gallery.php

77 Nisrine Boukhari, interview with the author, Damascus, June 2009.

78 The work was commissioned for an exhibition on the theme of traditional bath cultures entitled "Sharing Waters: Sauna Meets Hammam", and presented at Tutun Deposu in Istanbul in 2010. The work has not been shown in Syria. www.depoistanbul.net/en/event/exhibi tion-discussion-sharing-waters-sauna-meets-hamam-istanbul-2010/ (accessed 15 November 2019) .For more impressions of the work, see www.buthaynaali.com/Don $\% \mathrm{E} 2 \% 80 \% 99 \mathrm{t} \%$ 20listen! \%20She's\%20Only\%20a\%20Woman!.htm (accessed 15 November 2019).

79 Pollock (2003), p. 93.

80 See Marks (2003), pp. 42, 58 for a discussion of the practice of tying gender issues to societal ones among female Arab videomakers.

81 See also Bank (2008), for a discussion of this video.

82 For example, the growing numbers of veiled women on the streets of Damascus was commented on in a "classification" of different styles of hijab by the anonymous Syrian blogger "Pupetteer" in 2007. Available at: http://thoughts-journal.blogspot.de/2007/04/islamic-syria_ 06.html (accessed 15 November, 2019.

83 Delphine Leccas, personal communication.

84 Exhibitions have included "Mahrem, Notes on Veiling", a project by the Turkish sociologist Nilüfer Göle, shown in Istanbul and at the Tanas art space in Berlin in 2008, and "Taswir, Pictorial Mappings of Islam and Modernity", a project by Almuth Shulamith Bruchstein Çoruh at Martin Gropius Bau in Berlin in 2009-2010.

85 Springborg (1981), p. 192.

86 Reem Al-Ghazzi, conversation with the author, Damascus, August 2009.

87 The "Jazira", literally "island", comprises the regions of north-eastern Syria.

88 De Chatel (2014), pp. 1-2, 5.

89 Statement on Al-Beik's Vimeo page: https://vimeo.com/64006255 (accessed 15 November 2019.

90 al-Hammal was the Arabic title given in the exhibition program. In later publications, the title is given as al-'Attal, Lenssen (2014), p. 54. For an in-depth discussion of the painting and place in the oeuvre of Adham Ismail, see Lenssen (2017).

91 Lenssen (2014), p. 56.

92 See also ibid., pp. 54-57 for an analysis of this painting.

93 The film was mainly produced at the Arab Institute of Film in Amman under the supervision of Omar Amiralay. The later date of completion seems to indicate that it was finalized at a later stage.

94 Reem Ali, personal statement during a Q\&A session moderated by the author at a screening at the International Film Festival, Rotterdam, February 2012.

95 Imprisonment, especially for political reasons, and its conditions represent an important theme, especially in Syrian literature. One such example was Under the Sun, On the Sand by Ghassan Al-Jabai. Mohamad Malas went on to make the film Fauq al-raml taht al-shams (Under the Sun, On the Sand, 1999) in collaboration with Al-Jabai as a commemorative project for the occasion of the 50th anniversary of the UN's Universal Declaration of Human Rights. For a discussion of the category of "prison literature" in Syria, see cooke (2007), pp. 4, 121-144. For a discussion of Malas' film, see cooke (2011), pp. 180-181.

96 cooke (2007), p. 6.

97 Marks (2000), p. 29.

98 Mohamad Malas, conversation with author, October 2010.

99 Throughout the late 1970s and early 1980s, oppositional political activities by the Islamist opposition, the Ikhwan al-muslimin or Muslim Brotherhood presented a serious challenge to the regime of Hafiz Al-Assad. The Islamists launched a campaign of sabotage, which involved assassinations of Alawi elites and which continued in a series of attacks against government 
installations and violent mass demonstrations. The potential danger for the regime lay in the fact that several other groups, such as radical leftists and professional associations, allied themselves with the Islamists for tactical reasons, hoping that a weakened regime could either be brought down or transformed. An attempted assassination of the President in June 1980 led to a massive crackdown on dissent, which included the massacre of Islamist prisoners at the infamous Tadmur prison, the assassination of the exiled Ba'ath Party founder Salah AlDin Bitar in Paris and mass executions of Ikhwan activists and supporters, culminating in the killing of thousands of Islamists in the city of Hama in February 1982, an operation which also led to sweeping destruction of the historic city. See Hinnebusch (2001), pp. 98-103, for an outline of these events. For a history of the Tadmur prison, see Taleghani (2015).

100 cooke (2007), p. 113.

101 Shohat and Stam (1994), p. 288. See also cooke (2007), pp. 113-114.

102 Ibid., pp. 114-115.

103 Marks (2000), p. 66.

104 cooke (2007), p. 106. See also pp. 115-116, for a discussion of the controversy surrounding the production of the film.

105 Marks (2000), p. 2.

106 Rosler (2010), pp. 106, 108; Preda (2012), p. 901. However, the international interest in Iranian cinema, which relies to a large degree on allegory and symbols, seems to contradict this view. See Naficy (2002), p. 53, for a discussion of international interest in Iranian cinema. Syrian auteur films, whether or not their visual language is "obscure" (Boëx 2006) are not necessarily entirely inaccessible to outside audiences. During a programme of Syrian auteur films that I curated for the Arsenal Institute of Film and Video Art in Berlin in 2009, some German members of the audience expressed their surprise at the level of critique in these films. For this audience, not necessarily familiar with the complex context of Syrian authoritarianism, but certainly with the sophisticated language of art-house cinema, the different means with which Syrian filmmakers had veiled their criticism of the regime were quite lucid. The links between power structures in an extended family and those in a dictatorship needed no explanations. See www.arsenal-berlin.de/en/arsenal-cinema/past-programs/single/article/ 1697/2804//archive/2009/october.html. The programme comprised films by Omar Amiralay, Mohamad Malas, Oussama Mohammad, Abdellatif Abdelhamid, as well as experimental works by young filmmakers and videomakers.

107 See Gugler (2011), for a discussion of the film.

108 Cited in Hadria (2005), p. 34. See also Chapter 2, Section 2.1.

109 See Preda (2012), pp. 901, 903.

110 Egan (2011a), p. 52, and Egan (2011b), p. 99.

\section{Chapter 4}

1 See www.nytimes.com/2014/06/19/arts/international/syrian-artists-set-up-base-in-beirut.html? r $=0$ (accessed 15 November 2019).

2 See www.global-contemporary.de/en/artists/12-mladen-stilinovic (accessed 15 November, 2019).

3 In 2019, Imad Issa received some late international recognition, as he was invited to participate in the Venice Biennale, as part of the Iraqi national pavilion's exhibition "Heartbreak", organized by the Ruya Foundation, see www.ruyamaps.org/newsfeatures/heartbreak-exhibition-a nnouncement (accessed 15 November 2019).

4 For a discussion of "International Art English", see Rule and Levine (2013). See also Winegar (2008), p. 654.

5 Naef (2015), p. 496.

6 The curator Rasha Salti has pointed to the paradox that while these practices could easily be described as "situationist", conceptual artistic practice is not necessarily common knowledge among Syrian activists. See Salti (2012), p. 170.

7 To get an idea of these videos, see, e.g., a video by an activist group in Homs, that was subsequently entitled The Funniest Clip in the Syrian Revolution. Available at: www.youtube. $\mathrm{com} /$ watch? $\mathrm{v}=$ SkDjmO-eWE4 (accessed 15 November 2019). This short clip mocks the 
regime's claim that the uprising was led by armed gangs at a time when protests were still largely peaceful: in it, we see an "undercover reporter" visiting a group of "terrorists" armed with weapons made of vegetables, which they proudly display. See also Bank (2016a).

8 These sentiments have been expressed by a number of artists with whom I have discussed the issue.

9 See http://edn.network/news/news-story/article/a-call-from-syrian-filmmakers-to-filmmaker s-eve rywhere/activities/?tx_felogin_pi1\%5Bforgot $\% 5 \mathrm{D}=1$ \&tx_ttnews $\% 5 \mathrm{BbackPid} \% 5 \mathrm{D}=145 \& \mathrm{cHa}$ sh

=20d6ae20bbb46704eb8340b575a413f9 (accessed 15 November 2019). The original call no longer appears to be available online. See also Salti (2012), p. 169.

10 For a discussion of the filmmakers' call and its connection to previous activism by artists and intellectuals, see Salamandra and Stenberg (2015), p. 2.

11 As pointed out to me by Silvia Naef, similar notions were and are widespread about Iraq and its artists.

12 See https://newint.org/features/2015/09/01/syrian-revolution-and-thekingdom-of-silence/ (accessed 15 November 2019).

13 Winegar (2008), pp. 652-653.

14 Martin (1989a).

15 Ibid., pp. 8-9.

16 Buchloh and Martin (1989), p. 23.

17 Ibid., p. 22.

18 Martin (1989a), p. 9.

19 Buchloh and Martin (1989), p. 24.

20 Araeen (1989), pp. 4, 10-11.

21 Ibid., p. 4.

22 Martin (1989a), p. 9.

23 Araeen (1989), pp. 3-4; Buchloh and Martin (1989), p. 25.

24 Baykam (1994), p. 53.

25 In 2014, the Centre Pompidou organized a series of events to commemorate the 25 years that had passed since the exhibition. See www.centrepompidou.fr/cpv/resource/c5eRpey/rERz8A? param.espacePerso=false (accessed 15 November 2019). I did not have any opportunity to visit the documentary exhibition nor attend any of the other events or read the publication and therefore cannot provide a qualified view on the tenor of the re-assessment of this exhibition. But judging from the website of the event, which appear quite self-celebratory, it does not look as if the occasion to revise of some of the original critique was really used.

26 Kee (2011), p. 372.

27 Ibid., p. 372. See also Winegar (2008), p. 670, for a discussion on the stress on secularism and negative framing of Islam in exhibitions of Middle Eastern artists.

28 Ibid., p. 654.

29 Porter (2006), p. 14.

30 Farzin (2014), p. 92.

31 Naef (2010), p. 32.

32 See Winegar (2008), pp. 653-654, for a list of post-9/11 events related to Arab art in the USA.

33 David (1997); Farzin (2014), p. 92.

34 This is a subject that has been widely discussed, mostly in relation to individual artists. See e. g., Wu (2007), p. 725 and Vitali (2004), p. 2, concerning the artists Mona Hatoum and Shirin Neshat. See Winegar (2008), p. 655, for a discussion of the representation of artists from the Middle East as historically and/or religiously defined in the USA.

35 Kee (2011), p. 379.

36 Naef (2015), pp. 494-495.

37 Farzin (2014), p. 89.

38 Ibid., p. 89.

39 Porter (2006).

40 Farzin (2014), p. 93.

41 Winegar (2008), p. 654.

42 Behiery (2012), p. 131. 
43 Ibid., p. 131.

44 Farzin (2014), p. 93; Behiery (2012), p. 131.

45 Ibid., p. 138.

46 Ibid., p. 139.

47 Naef (2010), p. 36.

48 Farzin (2014), p. 93.

49 Winegar (2008), p. 675.

50 Naef (2015), p. 495.

51 Winegar (2008), pp. 674-677.

52 Persekian (2003), p. 96.

53 Sloman (2009), pp. 12-25.

54 Lenssen (2008).

55 Naef (2015), p. 475.

56 See http://edition.cnn.com/2011/TRAVEL/01/12/old.new.damascus/, and www.nytimes.com/ 2010/11/27/arts/27iht-scdamascus.html (accessed 15 November 2019).

57 Marks (2003), p. 42. Marks' observations are based on fieldwork in Lebanon.

58 Ibid., p. 53.

59 A map published in The New Yorker in 2018 gives an idea of the dispersion of artists from Syria. See www.newyorker.com/culture/culture-desk/mapping-the-journeys-of-syrias-artists (accessed 15 November 2019). Showing an impressive level of dispersion on a global level, it gives an incomplete image, as it seems to refer to the artists with whom the author has spoken and does not list all countries where artists from Syria have found refuge.

60 Many artists chose to work anonymously, through collective identities or by using pseudonyms. This need was triggered by some instances of artists' relatives being harassed and beaten up. For instance, the parents of the musician Malek Jandali were beaten up in their home in Damascus after their son had expressed his support for the uprising during a concert in Washington, where he was based, see https://freemuse.org/news/syria-parents-beaten-beca use-of-their-sons-music/ (accessed 15 November 2019). See Bank (2016a) for a discussion of the aspect of anonymity in the works of critical Syrian artists after 2011.

61 See ibid. for a discussion of this video.

62 Remarks made during the Q\&A session of the "Virtual Agoras" programme, which I curated for the 7th Berlin Biennale in 2012. See also Bank (2016a).

63 See www.theguardian.com/world/2011/may/31/syria-unrest-teenage-victim-hamza (accessed 10 December 2019) for an account of this case.

64 Matar (2014), p. 241.

65 A great number of more or less loosely curated spaces began to appear on the internet shortly after the beginning of the uprising. Some lasted longer than others, but they mostly presented highly diverse collections of creative works. In order to keep the focus on artistic projects in a narrower sense, I will not consider these projects here. See cooke (2017), pp. 73-89, for a presentation of a selection of such projects.

66 Hanano (2012).

67 See also cooke (2017), pp. 43-44.

68 The videos can be accessed on the group's YouTube channel: www.youtube.com/user/Masa sitMati/videos (accessed 15 November 2019).

69 See Bank (2016a) and cooke (2017), pp. 43-44.

70 See note 68.

71 Parts of the article can be read at: www.theatlantic.com/international/archive/2012/01/the-on ly-remaining-online-copy-of-vogues-asma-al-assad-profile/250753/ (accessed 15 November 2019).

72 Puppet Masters. Top Goon (2012), p. 14.

73 "Jameel", cited in ibid., p. 14.

74 See Halasa (2012).

75 Cited in cooke (2013), p. 31.

76 For details on the arrest of Abdelké and his decision to remain in Syria, see https://frieze.com/a rticle/what-remains, http://news.trust.org//item/20130724140733-vitwd/ (accessed 15 November 2019). 
77 The video can be accessed on the YouTube channel of Kinan Azmeh: www.youtube.com/wa tch? $\mathrm{v}=\mathrm{nD}$ 9jbBFKetA (accessed 15 November 2019).

78 See Bank (2019a) for a discussion of these works in relation to trauma work.

79 For an impression of the videos that were part of the installation, see https://vimeo.com/ 141963628;https://vimeo.com/141963276; https://vimeo.com/141962036; https://vimeo.com/ 141891450. For an idea of the entire set-up of the installation, see www.bissanealcharif.com/la nguage/fr/memoires-de-femmes/ (accessed 15 November 2019).

80 Marks (2000), p. 5.

81 See e.g., www.newyorker.com/magazine/2004/05/10/torture-at-abu-ghraib (accessed 15 November 2019).

82 Connelly (2012), pp. 90-91.

83 In many instances of imagery showing political violence and violence in the context of war and documented by the perpetrators of violence, the original intent has been to dehumanize the victims. But, as discussed by Christiana Spens, such images often have the reverse effect, when they become known to a wider public. Thus, they rather confirm the humiliated victims' humanity and as worthy of compassion. See Spens (2014), p. 57.

84 For an impression of this image, see www.atassifoundation.com/artists/mohamad-omran.

85 Connelly (2012), p. 115.

86 See Connolly (2012), p. 113 for a discussion of Otto Dix's veterans and their relation to the tradition of the grotesque.

87 Khalil Younes, cited in Halasa (2012), p. 17. For an impression of the works, see http://kha lilyounes.com/ (accessed 15 November 2019).

88 See also Bank (2014), p. 1, for a brief discussion of Marwan's early paintings and their relation to his personal life in Germany.

89 Hadria (2005), pp. 35-36.

90 Examples are: Ankori (2006); Boëx (2011a); Boullata (2009); cooke (2007); Lenssen (2014); Scheid (2005); Shaw (2011) and Winegar (2006). Other examples, not cited in this book are: Sam Bardaouil, Surrealism in Egypt: Modernism and the Art and Liberty Group (New York: I. B. Tauris, 2017); Liliane Karnouk, Modern Egyptian Art: 1910-2003 (Cairo: American University of Cairo Press, 2005); Adila Laïdi-Hanieh, Fahrelnissa Zeid: Painter of Inner Worlds (London: Art/Books, 2017); Nadia Radwan, Les modernes de l'Égypte. Une renaissance transnationale des Beaux-Arts et des Arts appliqués (Bern: Peter Lang, 2017).

91 Hadria (2005), p. 36.

92 See Bank (2018a), pp. 178-180, for a discussion of the opportunities of Syrian displaced artists in Berlin.

\section{Conclusion}

1 It would extend far beyond the limits of this study to attempt to give an overall picture of the exhibitions organized around Syrian themes and their reception by the media and the public. As examples, see www.theguardian.com/uk-news/2015/apr/19/syrian-artist-war-paintings-exhibition-london and www.box-freiraum.berlin/my-voice-rings-out-for-syria/ (accessed 10 December 2019).

2 Kobena Mercer, cited in Juneja (2011), p. 274.

3 See also ibid., p. 277, for a discussion of "authenticity" as a requirement for non-Western artists to access the international art scene.

4 Naef (2015), p. 489.

5 As the example of the Syrian-German artist Manaf Halbouni and his public installation "Monument" has shown, this potential might also be nullified by the recent surge of rightwing movements. See Bank (2018a), pp. 174-175 and Bank (2019a), pp. 137-139.

6 Many artists with whom I have spoken have expressed such concerns.

7 Plesu (1995), pp. 63-64. 


\section{Bibliography}

Adams, Jacqueline (2005). "When Art Loses its Sting: The Evolution of Protest Art in Authoritarian Contexts", Sociological Perspectives 48:4, 531-558.

Al-Attar, Najah (1986-1987). "How Great Is Art?", Al-hayat al-tashkiliyya 25-28, 2-3.

Alberro, Alexander (2009). "Institutions, Critique, and Institutional Critique", in Alexander Alberro and Blake Stimson, eds, Institutional Critique: An Anthology of Artists' Writings, Cambridge, MA: MIT Press, pp. 2-19.

Ali, Buthayna (2009). I'm Ashamed, self-published artist book.

Ali, Wijdan (1997). Modern Islamic Art: Development and Continuity, Gainesville, FL: University Press of Florida.

Alkassim, Samirah (2004). "Cracking the Monolith: Video and Film Art in Cairo", New Cinemas $2: 1,5-16$.

Alkassim, Samirah (2006). "Tracing an Archaeology of Experimental Video in Cairo", Nebula 3:1, 132-151.

Al Khatib, Reem and Yazaji, Rana (2010). "Cultural Policy Profiles: Syria”, in Cultural Policies in Algeria, Egypt, Jordan, Lebanon, Morocco, Palestine, Syria and Tunisia: An Introduction, Cultural Resource, Amsterdam: European Cultural Foundation and Boekmanstudies, pp. 174-200.

All Art Now (2008). "Here I Stand", exhibition catalogue, Damascus: All Art Now.

Al-Sharif, Tareq (1984-1985). "Al-fann al-tashkili al-mu'asir fi-suriya”, Al-haya al-tashkiliya, pp. 4-109.

Amiralay, Omar (2006). "Were It Not for Cinema", in Rasha Salti, ed., Insights into Syrian Cinema: Essays and Conversations with Contemporary Filmmakers, New York: Ratapallax Press, pp. 95-98.

Amiralay, Omar (2009). "Documentary, History and Memory", in Catherine David, Georges Khalil and Bernd M. Scherer, eds, Di/Visions, House of World Cultures and Forum Transregionale Studien, Göttingen: Wallstein, https://vimeo.com/137470700.

Ankori, Gannit (2006). Palestinian Art, London: Reaktion Books.

Arabi, Asaad (1995). "Matière de l'oubli et de la mémoire", in Fateh Al-Moudarres, Damascus: Atassi Gallery and Paris Institut du monde arabe, pp. 21-28.

Araeen, Rasheed (1989). "Our Bauhaus, Other's Mudhouse”, Third Text 3:6, 3-16.

Arnold, Marion (2013). "Here, There and In-Between: South African Women and the Diasporic Condition", in Marsha Meskimmon and Dorothy C. Rowe, eds, Women, the Arts and Globalization, Manchester: Manchester University Press, pp. 121-144.

Atassi, Mouna (1998). Contemporary Art in Syria, Damascus: Gallery Atassi.

Avez, Renaud (1993). L'Institut français de Damas au Palais Azem (1922-1946) à travers les archives, Damascus: Institut Français de Damas.

Ayyam (2008). Ayyam Gallery: Special Edition Catalogue, Damascus: Ayyam Gallery.

Ayyam (2011). The Samawi Collection: Curated Selections of Arab Art, Dubai: Ayyam Gallery. Available at: http://images.exhibit-e.com/www_ayyamgallery_com/5a1850bc.pdf 
Bahnassi, Afif (1974). Les styles de l'art contemporain en Syrie, UNESCO: Consultation collective sur les problèmes contemporains des arts arabes dans leurs relations socio-culturelles avec le monde arabe, Hammamet: UNESCO.

Bank, Charlotte (2008). "Veiled Visuality: Video Art in Syria”, ISIM Review 22. Available at: https:// openaccess.leidenuniv.nl/bitstream/handle/1887/17270/ISIM_22_Veiled_Visuality_Video_Art_in_Sy ria.pdf? sequence $=1$

Bank, Charlotte (2014). "Marwan: Topographies of the Soul”, in Marwan Qassab Bachi. Topographies of the Soul, Sharjah: Barjeel Art Foundation, pp. 1-3.

Bank, Charlotte (2016a). "Calling Things by Their Real Names: Anonymity and Artistic Online Production During the Syrian Uprising”, Fusion Journal 9, Anonymous: The Void in Visual Culture. Available at: www.fusion-journal.com/issue/009-anonymous-the-void-in-visual-culture/ calling-things-by-their-real-names-anonymity-and-artistic-online-production-during-the-syrian-up rising/.

Bank, Charlotte (2016b). "Painting as Critique: Oil Painting as a Site for Social and Political Negotiation in Syria”, in Silvia Naef and Elahe Helbig, eds, Special Issue, Visual Modernity in the Arab World, Turkey and Iran: Reintroducing the 'Missing Modern', Asiatische Studien / Études Asiatiques (ASI) 70:4, 1285-1306.

Bank, Charlotte (2018a). "Remaking a World: Recently Displaced Artists from Syria in Berlin", in Johanna Rolshoven and Joachim Schlör, eds, Special Issue, Artistic Positions and Representations of Mobility and Migration, Mobile Cultures Studies 4, 171-182.

Bank, Charlotte (2018b). "Translating Commitment: Some Thoughts on Critical Artistic Production in the Arab World", in Jelle Bouwhuis, ed., Special Issue, Furthering, nurturing and futuring Global Art Histories?, Kunstlicht 39:1, 35-42.

Bank, Charlotte (2019a). "Give Sorrow Images: Trauma and Loss in the Works of Displaced Artists from Syria”, in Lucy Wrapson, Victoria Sutcliffe, Sally Woodcock and Spike Bucklow, eds. Migrants: Art, Artists, Materials and Ideas Crossing Borders, London: Archetype Publications, pp. 130-140.

Bank, Charlotte (2019b). "Art Education in Twentieth Century Syria”, in Nino Nanobashvili and Tobias Teutenberg, eds, Drawing Education Worldwide! Continuities - Transfers - Mixtures, Heidelberg: University of Heidelberg Press, pp. 305-319.

Bank, Charlotte (2020). "Feminism and Social Critique in Syrian Contemporary Art", in Ceren Özpınar and Mary Kelly, eds, Under the Skin: Feminist Art from the Middle East and North Africa Today, Oxford: Proceedings of the British Academy (forthcoming).

Barakat, Saleh M. (2003). "The Place of the Image in the Levantine Interior: The Lebanese Case", in Bernard Heyberger and Silvia Naef, eds, La multiplication des images en pays d'Islam: de l'estampe à la télévision XVIIe-XXIe siècle, Actes du colloque, Images: fonctions et langages. L'incursion de l'image moderne dans l'Orient musulman et sa périphérie, Istanbuler Texte und Studien 2, Würzburg: Ergon Verlag, pp. 131-139.

Bardaouil, Sam (2016). "The Art and Liberty Group: Rupture, War and Surrealism in Egypt (19381948)", in Sam Bardaouil and Till Fellrath, eds, Art et Liberté: Rupture, War and Surrealism in Egypt (1938-1948), Paris: Skira, pp. 16-53.

Bardaouil, Sam and Fellrath, Till (eds) (2016). Art et Liberté: Rupture, War and Surrealism in Egypt (1938-1948), Paris: Skira.

Baykam, Bedri (1994). Monkeys' Right to Paint and the Post-Duchamp Crisis: The Fight of a Cultural Guerilla for the Rights of Non-Western Artists and the Empty World of the Neo-ReadyMades, Istanbul: Literatür, pp. 47-61.

Becker, Howard S. (1982). Art Worlds, Berkeley, CA: University of California Press.

Behiery, Valerie (2012). "Alternative Narratives of the Veil in Contemporary Art", Comparative Studies of South Asia, Africa and the Middle East 32:1, 130-146.

Boëx, Cécile (2006). "Tahyâ as-sînamâ! Produire du sens: les enjeux politiques de l'expression dans l'espace public", Revue des mondes musulmans et de la Méditerranée December, 115-116. Available at: http://remmm.revues.org/3035. 
Boëx, Cécile (2011a). "La contestation médiatisée par le monde de l'art en contexte autoritaire. L'expérience cinématographique en Syrie au sein de l'Organisme général du cinéma, 1964-2010”, $\mathrm{PhD}$ dissertation, Aix en Provence.

Boëx, Cécile (2011b). "The End of the State Monopoly over Culture: Toward the Commodification of Cultural and Artistic Production", Middle East Critique 20:2, 139-155.

Boullata, Kamal (2009). Palestinian Art, 1850-2005, London: Saqi.

Bourdieu, Pierre (1993). The Field of Cultural Production, ed. Randal Johnson, New York: Columbia University Press.

Buchloh, Benjamin H.D. and Martin, Jean-Hubert (1989). "Interview”, Third Text 3:6, 19-27.

Calirman, Claudia (2012). Brazilian Art under Dictatorship: Antonio Manuel, Artur Barrio, and Cildo Meireles, Durham, NC: Duke University Press.

Campbell, David (2004). "Horrific Blindness: Images of Death in Contemporary Media”, Journal for Cultural Research 8:1, 55-74.

Clark, T.J. (1973). Image of the People: Gustave Courbet and the 1848 Revolution. London: Thames and Hudson.

Conn, Steven (2002). "Narrative Trauma and Civil War History Painting, or Why Are These Pictures So Terrible?", History and Theory 41, 17-42.

Connelly, Frances S. (2012). The Grotesque in Western Art and Culture: The Image at Play, New York: Cambridge University Press.

cooke, miriam (2007). Dissident Syria: Making Oppositional Arts Official, Durham, NC: Duke University Press.

cooke, miriam (2011). "The Cell Story: Syrian Prison Stories after Hafiz Asad”, Middle East Critique 20:2, 169-187.

cooke, miriam (2013). “Tadmor's Ghosts”, Review of Middle East Studies 47:1, 28-36.

cooke, miriam (2017). Dancing in Damascus: Creativity, Resilience, and the Syrian Revolution, New York: Routledge.

Crapo, Paul B. (1991). "Disjuncture on the Left: Proudhon, Courbet and the Antwerp Congress of 1861”, Art History 14:1, 67-91.

Danko, Dagmar (2011). Zwischen Überhöhung und Kritik. Wie Kulturtheoretiker zeitgenössische Kunst interpretieren, Bielefeld: transcript Verlag.

David, Catherine (1997). "Documenta X: Introduction to the Short Guide”. Press release. Available at: http://universes-in-universe.de/doc/e_press.htm

Davidian, Vazken Khatchig (2014). "Portrait of an Ottoman Armenian Artist of Constantinople: Rereading Teotig's Biography of Simon Hagopian”, Revue arménienne des questions contemporaines 4, 11-54.

De Chatel, Francesca (2014). "The Role of Drought and Climate Change in the Syrian Uprising: Untangling the Triggers of the Revolution", Middle Eastern Studies 50:4, 521-535.

Deleuze, Gilles and Guattari, Félix (2013). A Thousand Plateaus, trans. B. Massumi, London: Bloomsbury.

Devictor, Agnès (2002). "Classic Tools, Original Goals: Cinema and Public Policy in the Islamic Republic of Iran (1979-1997)", in Richard Tapper, ed., The New Iranian Cinema: Politics, Representation and Identity, New York: I. B. Tauris, pp. 66-76.

Dickinson, Kay (2016). Arab Cinema Travels: Transnational Syria, Palestine, Dubai and Beyond, London: British Film Institute.

Dormröse, Ulrich (2012). "Einführung", in Geschlossene Gesellschaft. Künstlerische Fotografie in der DDR 1949-1989, Berlin:Berlinische Galerie, pp. 16-17.

Dressler, Iris (2010). "Subversive Practices: Art under Conditions of Political Repression: 60s-80s. South America / Europe", in Hans D. Christ and Iris Dressler, eds. Subversive Practices: Art under Conditions of Political Repression: 60s-80s. South AmericalEurope, Ostfildern: Württembergischer Kunstverein, pp. 38-56.

Dussaud, René (1927). "La mission du peintre Jean Ch. Duval en Syrie (1924)”, Syria, 8: 3, 248-253. 
Efimova, Alla (1997). "To Touch on the Raw: The Aesthetic Affections of Socialist Realism", Art Journal 56: 1, 72-80.

Egan, Eric (2011a). "Regime Critics Confront Censorship in Iranian Cinema", in Joseph Gugler, ed., Film in the Middle East and North Africa: Creative Dissidence, Austin, TX:University of Texas Press, pp. 37-62.

Egan, Eric (2011b). "Stray Dogs: Cruelty and Humanity amid Hardship in Afghanistan", in Joseph Gugler, ed., Film in the Middle East and North Africa: Creative Dissidence, Austin, TX:University of Texas Press, pp. 95-103.

El-Jeiroudi, Diana (2005). "Interview mit Gerald Matt", in Some Stories: Künstlerinnen aus Ägypten, Algerien, Iran, Libanon, Palästina, Syrien, und der Türkei zeigen in Film und Video Konstruktionen weiblicher Identität, Vienna: Kunsthalle Wien, pp. 40-41.

Ende, Werner (1984). "Wer ist ein Glaubensheld, wer ist ein Ketzer? Konkurrierende Geschichtsbilder in der modernen Literatur islamischer Länder", Die Welt des Islams, New Series 23/24, 70-94.

Escovitz, Joseph H. (1983). "Orientalists and Orientalism in the Writings of Muhammad Kurd Ali”, International Journal of Middle East Studies 15:1, 95-109.

Farzin, Media (2014). "Exhibit A: On the History of Contemporary Arab Art Shows”, in Kaelen Wilson-Goldie and Negar Azimi, eds, Here and Elsewhere, New York: New Museum, pp. 89-97.

Freitag, Ulrike (1999). "In Search of 'Historical Correctness': The Ba'th Party in Syria”, Middle Eastern Studies 35:1, 1-16.

Fuss, Peter (2001). Das Groteske: Ein Medium des kulturellen Wandels, Cologne: Böhlau.

George, Alan (2003). Syria: Neither Bread Nor Freedom, London: Zed Books.

Ghadbian, Najib (2001). "Contesting the State Media Monopoly: Syria on Al-Jazira Television", Middle East Review of International Affairs 5:2, 75-87.

Gugler, Josef (2011). "The Extras (Nabil Maleh). Lovers Suffer the Twin Repressions of Patriarchal Culture and a Police State", in Joseph Gugler, ed., Film in the Middle East and North Africa: Creative Dissidence, Austin, TX:University of Texas Press, pp. 125-133.

Hadria, Michèle Cohen (2005). "Nothing New Under the Western Sun. Or the Rise of the Arab Experimental Documentary", Third Text 19:1, 33-43.

Halasa, Malu (ed.) (2012). Culture in Defiance: Continuing Traditions of Satire, Art and the Struggle for Freedom in Syria, Amsterdam: Prince Claus Fund for Culture and Development.

Hanano, Amal (2012). "The Real Me and the Hypothetical Syrian Revolution (Part 2)", Jadaliyya. Available at: www.jadaliyya.com/pages/index/4788/the-real-me-and-the-hypothetical-syri an-revolution

Hegasy, Sonja (2010). "Representing Change and Stagnation in the Arab World: Re-thinking a Research Design", The Mediterranean Review, 3:2, $23-42$.

Hinnebusch, Raymond (2001). Syria: Revolution from Above, London: Routledge.

Hinnebusch, Raymond (2012). “Syria: from 'Authoritarian Upgrading' to Revolution?”, International Affairs 88:1, 95-113.

Hussam Al-Din, Muhammad and Hassan, Abu Ayyash (1988). Taufiq Tareq, Michael Kirsheh, Syrian Plastic Arts Series 1, Damascus: Alsahani Establishment.

Hussam al-Din, Muhammad and Hassan, Abu Ayash (1991). M. Jalal, A. A. Al Sououd, K. Monaz, A. A. Arnaout, Syrian Plastic Arts Series 3, Damascus: Salhini Printing and Publishing.

International Crisis Group (2004). "Syria Under Bashar II: Domestic Policy Challenges", ICG Middle East Report No. 24. Brussels: International Crisis Group.

Johnson, Randal (1993). "Introduction", in Pierre Bourdieu, The Field of Cultural Production, New York: Columbia University Press, pp. 1-25.

Juneja, Monica (2011). "Global Art History and the 'Burden of Representation”, in Hans Belting, Jacob Birken, Andrea Buddensieg, and Peter Weibel, eds, Global Studies: Mapping Contemporary Art and Culture, Ostfildern: Hatje Cantz, pp. 274-297.

Karkutli, Burhan (1981). Grafik der Revolution. Burhan Karkutli. Ein palästinensischer Künstler, Frankfurt/Main: Rita G. Fischer Verlag. 
Kayali, Louay (2008). Hasasiya al-fanan, ka-fard wa dawruha fi al-nazaha [The Sensitivity of the Artist, as an Individual, and its Role in Artistic Integrity], reprinted in Tarek al-Sharif, (ed.) Louay Kayyali: Hadatha Fanniyya...wa Madmun Insani [Louay Kayali: Artistic Modernity... with a Human Approach], Damascus: General Secretariat of Damascus Arab Capital of Culture, p. 91.

Kee, Joan (2011). "Introduction: Contemporary Southeast Asian Art", Third Text 25:4, 371-381.

Keiso, Fassih (2006). A Brief Survey of Media Art in the Arab Region: Mesh 19 Global/Regional Perspectives, Melbourne: Experimenta Media Arts, unpaginated.

Klemm, Verena (2000): "Different Notions of Commitment (Iltizam) and Committed Literature (aladab al-multazim) in the Literary Circles of the Mashriq", Arabic and Middle Eastern Literatures 3:1, 51-61.

Komaromi, Ann (2007). "The Unofficial Field of Late Soviet Culture”, Slavic Review 66:4, 605-629.

LaCoss, Don (2010). "Egyptian Surrealism and 'Degenerate Art' in 1939”, The Arab Studies Journal $18: 1,78-117$.

Lenssen, Anneka (2008). “The Seasons of Tell-Al Hejara, Damascus”, Bidoun 13, 122.

Lenssen, Anneka (2011). Archive Map: Syria, Cairo: Townhouse Gallery. Available at: http://spea kmemory.org/uploads/ArchiveMapSyria.pdf

Lenssen, Anneka (2013). “The Plasticity of the Syrian Avant-Garde 1964-1970”, Art Margins 2:2, 43-70.

Lenssen, Anneka (2014). "The Shape of the Support: Painting and Politics in Syria's Twentieth Century", PhD dissertation, Massachusetts Institute of Technology.

Lenssen, Anneka (2017). "Adham Isma'il's Arabesque: The Making of Radical Arab Painting in Syria”, Muqarnas 34, 223-258.

Lenssen, Anneka, Rogers, Sarah and Shabout, Nada (eds) (2018). Primary Documents, New York: Museum of Modern Art.

Lundgren-Jörum, Emma (2012). "Discourses of a Revolution: Framing the Syrian Uprising”, Ortadoğu Etütleri 3:2, 9-39.

Maari, Boutros (2006). "Tradition populaire et création artistique: L'émergence de la peinture moderne en Syrie", PhD dissertation, Paris: Ecole des hautes études et sciences sociales.

Maghribi, Reem (2011). "Raising the Flag: Atassi Gallery”, Canvas, July/August, 68-77.

Maleh, Nabil (2006). "Scenes from Life and Cinema", in Rasha Salti, ed. Insights into Syrian Cinema: Essays and Conversations with Contemporary Filmmakers, New York: Ratapallax Press, pp. 87-94.

Marks, Laura U. (2000). The Skin of the Film: Intercultural Cinema, Embodiment, and the Senses, Durham, NC: Duke University Press.

Marks, Laura U. (2003). "What Is That and between Arab Women and Video? The Case of Beirut”, Camera Obscura 54, 18:3, 41-69.

Marks, Laura U. (2015). Hanan al-Cinema: Affections for the Moving Image, Cambridge, MA: The MIT Press.

Martin, Jean-Hubert (1989a). Magiciens de la terre, Paris: Editions du Centre Pompidou.

Martin, Jean-Hubert (1989b). "Préface", in Jean-Hubert Martin, Magiciens de la terre, Paris: Editions du Centre Pompidou, pp. 8-11.

Marwan (1998). An die Kinder Palästinas, Munich: Goethe Institut.

Massad, Joseph A. (2007). Desiring Arabs, Chicago: The University of Chicago Press.

Matar, Amer (2014). “Art \& Freedom”, in Malu Halasa, Zaher Omareen, and Nawara Mahfoud, eds, Syria Speaks: Art and Culture from the Frontline, London: Saqi Books, pp. 240-255.

Mathur, Saloni (2011). “A Retake of Sher-Gil's Self-Portrait as Tahitian”, Critical Inquiry 37:3, 515-544.

Meskimmon, Marsha (2011). "Making Worlds, Making Subjects: Contemporary Art and the Affective Dimension of Global Ethics", World Art, 1:2, 189-196.

Meskimmon, Marsha and Rowe, Dorothy C. (2013). "Editorial Introduction: Ec/centric Affinities: Locations, Aesthetics, Experiences", in Marsha Meskimmon and Dorothy C. Rowe, eds, Women, the Arts and Globalization: Eccentric Experience, Manchester: Manchester University Press, pp. 1-14. 
Muhanna, Nadia (2008). "King of Darkness", Syria Today, February, 47-48.

Naef, Silvia (1996). A la recherche d'une modernité arabe. L'évolution des arts plastiques en Egypte, au Liban et en Irak, Geneva: Slatkine.

Naef, Silvia (2001). "Portrait de femmes. Figuration de la féminité dans l'art contemporain du machrek", Horizons Maghrebins 44, 53-61.

Naef, Silvia (2002). "Between Symbol and Reality: The Image of Women in Twentieth-Century Arab Art", in Randi Deguilhem and Manuela Marin, eds, Writing the Feminine: Women in Arab Sources, New York: I.B. Tauris, pp. 221-235.

Naef, Silvia (2003). "Peindre pour être moderne? Remarques sur l'adoption de l'art occidental dans l'Orient arabe", in B. Heyberger and Silvia Naef, eds, La multiplication des images en pays d'Islam - De l'estampe à la télévision - (17e-21e siècles), Istanbul and Würzburg: Orient-Institut/ Ergon Verlag, pp. 189-207.

Naef, Silvia (2010). "Exhibiting the Work of Artists from 'Islamic' Backgrounds in the West. Current Practices and Future Perspectives", West Coast Line 64: Orientalism \& Ephemera 43:4, 30-37.

Naef, Silvia (2015). "Not Just 'For Art's Sake': Exhibiting Iraqi Art in the West After 2003", in Jordi Tejel, Peter Sluglett, Riccardo Bocco and Hamit Bozarslan, eds, Writing the Modern History of Iraq: Historiographical and Political Challenges, Singapore: World Scientific Publishing, pp. $475-499$.

Naficy, Hamid (2002). "Islamizing Film Culture in Iran: A Post-Khatami Update", in Richard Tapper, ed., The New Iranian Cinema: Politics, Representation and Identity, New York: I.B. Tauris, pp. 26-65.

Nashashibi, Salwa Mikdadi (1998). "Gender and Politics in Contemporary Art: Arab Women Empower the Image", in Sherifa Zuhur, ed., Images of Enchantment: Visual and Performing Arts of the Middle East, Cairo: The American University of Cairo Press, pp. 165-182.

Nochlin, Linda (1982). "The De-Politicization of Gustave Courbet: Transformations and Rehabilitation under the Third Republic", October 22, 64-78.

Ory, Pascal and Sirinelli, Jean-François (1986). Les intellectuels en France, de l'Affaire Dreyfus à nos jours, Paris: Armand Colin.

Pace, Joe and Landis, Joshua (2012). "The Syrian Opposition: The Struggle for Unity and Relevance, 2003-2008”, in Fred H. Lawson, ed., Demystifying Syria, London: Saqi and London Middle East Institute SOAS, pp. 120-143.

Persekian, Jack (2003). “A Diary of Disorientation”, in DisOrientation: Contemporary Arab Artists from the Middle East, Berlin:House of World Cultures, pp. 94-99.

Perthes, Volker (2004a). Syria Under Bashar Al-Assad: Modernization and the Limits of Change, Oxford: Oxford University Press.

Perthes, Volker (2004b). "Syria", in Volker Perthes, ed., Arab Elites: Negotiating the Politics of Change, Boulder, CO: Lynne Rienner Publishing, pp. 87-114.

Plesu, Andrei (1995). "Intellectual Life under Dictatorship”, Representations 49, 61-71.

PLO (1978). International Art Exhibition for Palestine, Beirut: Plastic Arts Section.

Pollock, Griselda (2003). Vision and Difference: Feminism, Femininity and the Histories of Art, New York: Routledge.

Porteous, Rebecca (1995). "The Dream: Extracts from a Film Diary by Muhammad Malas", Alif: Journal of Comparative Poetics 15, 208-228.

Porter, Venetia (2006). Word into Art: Artists of the Modern Middle East, London: British Museum Press.

Preda, Caterina (2012). “Artistic Critiques of Modern Dictatorships”, The European Legacy 17:7, 899-917.

Puppet Masters. Top Goon (2012). In Malu Halasa, ed., Culture in Defiance: Continuing Traditions of Satire, Art and the Struggle for Freedom in Syria, Amsterdam: Prince Claus Fund for Culture and Development, pp. 13-15.

Qashlan, Mamdouh (2006). Nusf Qarn min al-Ibda' al-Tashkiliyy fi-Suriyya, Damascus: Ebla li-lfunun al-jamila. 
Radwan, Nadia (2011). "Les arts visuels de l'Égypte moderne, méthodes de recherches et sources: l'example de Mahmûd Mukhtâr (1891-1934)”, Qaderns de la Mediterrània 15, 51-61.

Rosler, Martha (1990). "Video: Shedding the Utopian Moment", in Doug Hall and Sally Jo Fifer, eds, Illuminating Video: An Essential Guide to Video Art, New York: Aperture, pp. 31-50.

Rosler, Martha (2010). "Take the Money and Run? Can Political and Socio-Critical Art 'Survive'?", in Julieta Aranda, Brian Kuan Wood, and Anton Vidokle eds, What Is Contemporary Art?, e-flux journal, Berlin:Sternberg Press, pp. 104-140.

Rule, Alix and Levine, David (2013). International Art English . Available at: www.canopycanop ycanopy.com/contents/international_art_english

Said, Edward (1979). Orientalism, New York: Vintage Books.

Said, Edward (1994). Representations of the Intellectual: The 1993 Reith Lectures, London: Vintage Books.

Salamandra, Christa (2004). A New Old Damascus: Authenticity and Distinction in Urban Syria, Bloomington, IN: IndianaUniversity Press.

Salamandra, Christa (2008). "Creative Compromise: Syrian Television Makers between Secularism and Islamism”, Contemporary Islam 2:3, 177-189.

Salamandra, Christa (2015). "Syria's Drama Outpouring : Between Complicity and Critique", in Christa Salamandra and Leif Stenberg, eds, Syria from Reform to Revolt, vol. 2. Culture, Society, and Religion, Syracuse, NY: Syracuse University Press, pp. 36-52.

Salamandra, Christa and Stenberg, Leif (2015). "Introduction: A Legacy of Raised Expectations”, in Christa Salamandra and Leif Stenberg, eds, Syria from Reform to Revolt, vol. 2. Culture, Society, and Religion, Syracuse, NY: Syracuse University Press, pp. 1-15.

Salloum, Jayce (2005). "In/tangible Cartographies”, Third Text 19:1, 27-31.

Salti, Rasha (2006). "Critical Nationals: The Paradoxes of Syrian Cinema", in Rasha Salti, ed., Insights into Syrian Cinema: Essays and Conversations with Contemporary Filmmakers, New York: Ratapallax Press, pp. 21-44.

Salti, Rasha (2012). "Shall We Dance?”, Cinema Journal 52:1, 166-171.

Sarkissian, Hrair (2011). "The Past”, in Sharjah Biennial 10, Sharjah: Sharjah Art Foundation, pp. 349-354.

Sartre, Jean-Paul (1993). What Is Literature?, trans. Bernard Frechtman, New York: Routledge.

Scheid, Kirsten (2005). "Painters, Picture-Makers, and Lebanon: Ambiguous Identities in an Unsettled State”, PhD dissertation, Princeton University.

Scheid, Kirsten (2010). "Necessary Nudes: Hadatha and Mu'asira in the Lives of Modern Lebanese", International Journal of Middle Eastern Studies 42, 203-230.

Scott, James C. (1990). Domination and the Arts of Resistance: Hidden Transcripts, New Haven, CT: Yale University Press.

Shabout, Nada (2007). Modern Arab Art: Formation of an Arab Aesthetic, Gainesville, FL: University of Florida Press.

Shaw, Wendy M. K. (2011). Ottoman Painting: Reflections of Western Art from the Ottoman Empire to the Turkish Republic, New York: I.B. Tauris.

Shohat, Ella and Stam, Robert (1994). Unthinking Eurocentrism: Multiculturalism and the Media, London: Routledge.

Sjeklocha, Paul and Mead, Igor (1967). Unofficial Art in the Soviet Union, Berkeley, CA: University of California Press.

Sloman, Paul (ed.) (2009). Contemporary Art in the Middle East, London: Black Dog Publishing. Smith, Terry (2006). "Contemporary Art and Contemporaneity", Critical Inquiry 32:4, 681-707.

Smith, Terry (2011). "Currents of Worldmaking in Contemporary Art”, World Art 1:2, 171-188.

Sontag, Susan (2003). Regarding the Pain of Others, New York: Picador.

Sparre, Sara Lei (2008). "Educated Women in Syria: Servants of the State, or Nurturers of the Family?", Critique: Critical Middle Eastern Studies 17:1, 3-20.

Spens, Christiana (2014). "The Theatre of Cruelty: Dehumanization, Objectification and Abu Ghraib”, Contemporary Voices: St Andrews Journal of International Relations 5:3, 49-69. 
Springborg, Robert (1981). "Baathism in Practice: Agriculture, Politics, and Political Culture in Syria and Iraq", Middle Eastern Studies 17:2, 191-209.

Takieddine, Zena (2010). "Arab Art in a Changing World”, Contemporary Practices 7, 54-61.

Takkenberg, Lex (2010). “UNRWA and the Palestinian Refugees after Sixty Years: Some Reflections”. Available at: www.unrwa.org/userfiles/20100610957.pdf (15 November 2019).

Taleghani, R. Shareah (2015). "Breaking the Silence of Tadmor Military Prison", Middle East Report 275. Available at: www.merip.org/mer/mer275/breaking-silence-tadmor-military-prison

Terman, Rochelle L. (2010) “To Specify or Single Out: Should We Use the Term 'Honor Killing'?”, Muslim World Journal of Human Rights 7:1, 1-39.

Toukan, Hanan (2015). "Whatever Happened to Iltizam? Words in Arab Art after the Cold War", in Friederike Pannewicj and Georges Khalil together with Yvonne Albers, eds, Commitment and Beyond: Reflections on/of the Political in Arabic Literature since the 1940s, Wiesbaden: Reichert Verlag, pp. 333-349.

Tramontini, Leslie (2013). "Speaking Truth to Power? Intellectuals in Iraqi Baathist Cultural Production”, Middle East - Topics \& Arguments 01, 53-61.

Vitali, Valentina (2004). "Corporate Art and Critical Theory: On Shirin Neshat”, Women: A Cultural Review 15/1, 1-18.

Wallach, Amei (1991). "Censorship in the Soviet Bloc", Art Journal 50: 3, 75-83.

Wang, Dan S. (2003). "Practice in Critical Times: A Conversation with Gregory Sholette, Stephanie Smith, Temporary Services, and Jacqueline Terrassa”, Art Journal 62:2, 68-81.

Weber, Stefan (2002). "Images of Imagined Worlds: Self-image and Worldview in Late Ottoman Wall Paintings of Damascus", in Jens Hanssen, ed., The Empire in the City: Arab Provincial Capitals in the Late Ottoman Empire, Würzburg: Ergon Verlag, pp. 146-171.

Wedeen, Lisa (1999). Ambiguities of Domination: Politics, Rhetoric, and Symbols in Contemporary Syria, Chicago: University of Chicago Press.

Winegar, Jessica (2006). Creative Reckonings: The Politics of Art and Culture in Contemporary Egypt, Stanford, CA: Stanford University Press.

Winegar, Jessica (2008). "The Humanity Game: Art, Islam and the War on Terror", Anthropological Quarterly 81:3, 651-681.

Wu, Chin-Tao (2007). "Worlds Apart: Problems of Interpreting Globalised Art", Third Text 21:6, 719-731.

Zayat, Elias (2008). "Introduction", in Revival of Plastic Art Memory in Syria, vol. I. From the Beginnings Until the Sixties of the Twentieth Century: Selections from the National Museum Collections in Damascus, Damascus: Ministry of Culture, pp. 16-20. 